\title{
Some characteristics of deverbal nominals in Slavic and Romance languages
}

\author{
Ivica Peša Matracki and Vinko Kovačić (Zagreb)
}

\begin{abstract}
In this paper we will investigate the nature of deverbal nominals across languages. Deverbal nouns are typically classified according to their word-formation model: affixation and conversion. Our study will compare the word formation of deverbal nominals in Slavic (Croatian, Slovenian and Polish) and Romance languages (Italian, French and Spanish) in order to show (i) that affixation corresponds to a specific mode of morphological operations and (ii) that the differences and similarities between deverbal nominals of these two language families follow from the properties of the base verbs. Furthermore, our analysis will try to shed some light on the distinction between nouns and verbs. The paper comprises three major thematic parts. The first part briefly reviews the basic notions and theoretical assumptions of Generative Grammar regarding word formation. We have especially tried to explain those notions that we draw from Distributed Morphology. This part further exposes the theoretical framework that is used in this paper. In the second part, deverbal nominals in Slavic languages are analysed and described. We primarily investigate the Slavic languages, since in these languages morphology plays a larger role in the construction of deverbal nouns. The third part contains an investigation of the phrasal structure of nominalizations across the Romance languages. We close the work with a general conclusion about the behaviour of deverbal nouns in these two groups of languages. We concentrate mainly on the differences between the phrasal architecture of nominalizations and correspondent verbal constructions.
\end{abstract}

\section{$1 \quad$ Introduction}

In this chapter we expose the basic principles of the two main approaches to word formation found in Generative Grammar.

There is no single approach to morphology in generative grammar. Scholars in the field have advocated both lexical approaches (cf. Allen 1978; Selkirk 1982; Di Sciullo and Williams 1987; Aronoff 1994; Scalise 1994), ${ }^{1}$ and non-lexical - i. e. syntactic - approaches (cf. Travis 1984;

\footnotetext{
${ }^{1}$ The lexical approaches incorporate also Separationist Morphology (cf., e. g., Beard 1995). In this model, there is no direct connection between the aspect of morphology that deals with phonological features and those that deal with syntax and semantics; this implies "that morphological spelling has no access to the internal workings of derivation" (Ibid.: 50). Similarly, Anderson argues that morphological processes are distinct from syntactic ones; he separates inflection from derivation (the Split Hypothesis): "The Morphosyntactic Representation of a word is the only aspect of it that is visible to/in the syntax." (1992: 90). These two models conflict with the strongest form Linguistik online 77, 3/16 - http://dx.doi.org/10.13092/lo.77.2906
}

CC by 3.0 
Baker 1985, 1988; Lieber 1992). Lexical morphology sees word formation as a process with its own rules and laws. In other words, syntax does not take into account the internal organization of words. This means that the internal structure of words is syntactically irrelevant and complex words cannot be created on the basis of syntactic constructions or operations. Consequently, all word formation is completed before lexical insertion.

There are no lexical categories or affix morphemes (i. e., there is no Lexicon) in Distributed Morphology (DM). ${ }^{2}$ In DM, the word has no theoretical status; this implies that the formation of all types of language units occurs in a similar manner. ${ }^{3}$ In other words, lexical units are formed by the same mechanisms of construction as are syntactic units - i. e., they are created by syntactic-structure-forming operation. According to DM, all word formation belongs to syntax, and words are formed like syntactic phrases; the structure of words is determined by the syntax and not by subcategorization frames. ${ }^{4}$ Word formation occurs by means of categorically undefined roots combining with functional heads. The abstract root becomes a noun, verb or adjective depending on whether the nearest c-commanding node is the functional category $v, n$ or $a$ (cf. Halle/Marantz 1994; Halle 1997; Harley/Noyer 1998, 1999; Alexiadou 2001 for related views). ${ }^{5}$ Syntax generates structures by combining morphosyntactic features selected on the base of their importance for syntactic and semantic interpretation at LF; root/all other grammatical units, i. e. syntactic categories have no phonological content in pre-syntactic phase (only after syntax) - this is Strict Modularity II. ${ }^{6}$ In DM, functional heads entirely determine the category of lexical head. In this way, it differs from Grimshaw (1990), according to whom the category of lexical head determines its functional category. The descriptive and explanatory success of Pollok's Split-INFL Hypothesis led to a quick proliferation of the functional elements constituting the fundamental clause structures: Agrs, Agro, Tense Aspect, vP, AgrPastPart, PerfP, Mood, Modality, NumP etc. However, this proliferation raises the question of where the splitting process will stop, that is, the point when one will postulate the functional elements of syntactic computations (cf., e. g. Chomsky 1995, 2001; Cinque and Rizzi 2008). ${ }^{7}$

Chomsky (1995: 146-150) proposes the abandonment of the Agr-based theory of clause structure and the Split-INFL hypothesis of Pollock (1989) more generally, in favor of a single INFL projection where nominative Case, agreement and the EPP (Extended Projection Principle), feature of $\mathrm{T}$ are checked within a single projection, Tense Phrase (TP), (Chomsky 1995: 349; 2001: 4).

of the Lexicalist Hypothesis. Separationism also characterizes the theory of Distributed Morphology which has three core properties: Late Insertion, Underspecification and Syntactic Hierarchical Structure (Harley and Noyer 1999). We believe the claim of late insertion, resulting in the separation of the grammatical form from the actual phonological realization, as Anderson, Beard and the proponents of DM believe, remains unproven.

2 This model was proposed by Halle and Marantz (1993).

${ }^{3}$ Moreover, it means that category labels are irrelevant - i. e., the conventional sentence elements such as noun, verb, and adjective have no universal significance.

${ }^{4}$ Linguists who are proponents of DM actually adopt a strictly syntactic framework for the analysis of morphology.

${ }^{5}$ For example, a verb is a root whose nearest c-commanding functional elements are v, Aspect and Tense.

${ }^{6}$ According to Marantz (2001: 9), "on Strict Modularity II, there is only one mechanism in grammar for combining atomic units of structure and meaning, i. e., the Syntax".

${ }^{7}$ With no limitation on the number and type of functional elements, however, DM runs the risk of being unfalsifiable. To the question mentioned above, the simplest answer may be the following: one morphosyntactically relevant property presents one feature, i. e., one head.

ISSN 1615-3014 
In DM, eventivity/processness is defined by the presence of verbal functional categories. Grimshaw (1990), Alexiadou (2001) etc. assumed that agentive and complex event nominals have both nominal and verbal functional categories, whereas all other nouns have only nominal functional categories. According to Alexiadou (2001: 16), complex event nominals contain verbal functional layers such as Voice/v, Aspect, projections related to the expression of eventivity and Viewpoint Aspect. The light verb includes processness, agentivity and causality (ibid.: 17). ${ }^{8}$ It merges with the root to form the verb, it has an external argument in its specificator and it realizes the relationship with its object.

The verbal functional head Aspect contains semantic properties of the event/process. The aspect marker and presence of aspectual adverbs are two inseparable qualities for the assumption of the Aspect head in a structure. The structure of these nominals includes an abstract root inserted under vP and AspP; both functional heads can occur under Tense and D/Number. Aspect is a syntactic-semantic marker, while gender is a morphological marker even in Slavic languages (cf. Alexiadou 2001; for further discussion cf. Fowler 1996; Harely/Noyer 1999; Travis 2005; among others).

Chomsky (1995: 235-241; 2001: 7-10) believes that a classical perspective on the lexicon and lexical forms is more appropriate because dividing lexical categories into roots and functional heads additionally complicates the description: "Functional categories lacking semantic features require complication of phrase structure theory [...]" (ibid.: 43). The basic differences between these two approaches (lexical and purely syntactic) include the atomicity of lexical forms at the syntactic level, the presence of phonological features as early as during lexical insertion, and the place of word-formation rules in the grammar. Chomsky (1995: 130) assumes, in essence, that the output of some word-formation component consists of fully created lexical elements with a set of properties which may be relevant for syntax, but with an untransparent internal structure, although these outputs must move through the syntactic tree (X-bartheoretical conditions) - i. e., this movement is not morphological in nature. ${ }^{9}$

In this section we tried to clarify the main notions and problems that are discussed in the rest of the article.

\section{Some theoretical and methodological assumptions}

In this chapter we develop the foundation for a practical discussion about different languages that will serve as anchors and points of departure for the argumentation.

Process event nominals contain a group of functional projections that are connected with the verbal clause, while result nominals do not have such projections. This means that event characteristics are tied to special functional nodes within the tree and are not related to particular lexical categories or words (cf., e. g., Alexiadou 2001; Alexiadou/Grimshaw 2008).

\footnotetext{
${ }^{8}$ Harely and Noyer (1998: 120) defines the content of little $v$ as CAUSE, BECOME and BE, but this set of features provided by Universal Grammar (UG) is not limited to them. DM also assumes that verbal prefixes are located in $v$.

${ }^{9}$ Our interpretation of Chomsky's point of view is confirmed by the following passage: "We distinguish the lexicon from the computational system of the language, the syntax in a broad sense (including phonology). [...] The lexicon is a set of lexical elements, each an articulated system of features." (Chomsky 1995: 130).
} 
Event and/or process nominals v/VoiceP and AspectP contain syntactic groups that relate to an event and an aspectual point of view. Evidence for this is morphological in nature and the existence of adverbs. Adverbs of this type are not allowed with nominals formed from unergative verbs. ${ }^{10}$ Result nominals have no obligatory arguments and aspectual modifiers. In other words, they cannot be modified by temporal adverbs. ${ }^{11}$ As has been widely argued for in the literature, we distinguish between two classes of nominals: complex event nominals vs. result nominal, which include simple event nominals. In this paper, we refer to nouns that denote complex events simply as event/process nominals.

On the basis of the theoretical considerations exposed above, we have created the following working assumptions as the foundation on which we can build further investigations and develop our arguments: ${ }^{12}$

1. There is not a strong dichotomy between the lexicon and syntax and the corresponding difference between the external grammatical structure (relations between words and groups) and the internal grammatical structure (relations between word parts), but there is a clear distintcion between the structure of words, which is the domain of morphology, and the structure of sentences, which is the domain of syntax.

2. The verb has a very limited number of argument types. ${ }^{13}$ There are only a small number of verbs that have three arguments, and the number of thematic roles of these arguments is also small. This stands in opposition to the syntactic structure of the sentence, the complexity of which is without limits. ${ }^{14}$

3. Nouns denoting events govern the arguments in the nominal phrase in the same way that verbs govern arguments in the sentence, but there are differences in the morphosyntactic realization of the argument. The realization of noun arguments is more a possibility than a requirement, and they are not obligatory as are verb arguments.

4. Agentive nominals are similar to event nominals because their structure also contains verbal functional categories alongside nominal ones. Verbal functional categories in the structure of nominals define the eventness of nominals, but the eventness of nominals is different from the verbal event/process. Prototypical nouns denote objects or entities, whereas prototypical verbs

\footnotetext{
${ }^{10} \mathrm{We}$ will see that there is counter-evidence for this claim in the Croatian language. Aspect adverbs are tied to aspect group while manner adverbs are tied to vP or VoiceP (cf. also Birtić 2008).

${ }^{11}$ For important differences between complex event nominals, result nominals and simple event nominals, cf. Alexiadou and Grimshaw (2008). For further discussion of these differences, cf. Zubizarreta (1987), Pustejovski (1995), Picallo (1999), Balvet (2011), Badia (2002), Grimshaw (1990), Alexiadou (2001), Alonso (2004) etc.

${ }^{12}$ We have assumed here, in essence, a general lexical framework (as described by Di Sciullo and Williams 1987; Aronoff 1994; Chomsky 1995 etc.). According to this approach, we rest on the notion that only the stems of the lexical categories $(\mathrm{N}, \mathrm{V}, \mathrm{A})$ are morphemes in the traditional sense, i. e., the connection between meaning and sound.

13 The correlation between the event interpretation and the obligatory realization of argument structure has been an important point since Grimshaw (1990).

${ }^{14}$ For example, Hale and Keyser (1998) differentiate between lexical syntax and sentence syntax.
} 
denote actions or relations. ${ }^{15}$ Nouns, even when they denote actions and processes, seem to fix the course of an event or process in a moment, like a separate entity. ${ }^{16}$

5. Derivational morphology (word formation) deals with the bound realization of categories and elements that are entirely internal to minimal projections.

6. The uncontroversial prototypical major classes of lexical items (nouns, verbs and adjectives) consist of non-null, mutually implied phonological, grammatical, and semantic representations.

To test our working hypothesis, we have collected broad data, taking into account the following seven parameters:

1. defining the verb based on transitivity;

2. defining the number and types of arguments in nominals related to their different thematic roles;

3. defining how arguments are realized in morphosyntactic structures;

4. defining the structure of events expressed by the verbal nominal (process, states, achievements, transfer from one state to another, acting upon an object, internal object, achieving a goal etc.);

5. defining the syntactic, i. e., morphosyntactic, behaviour of nominals in their formation from verbs that possess the same verbal categories;

6. defining how suffixes contribute to the semantic characteristics of verbal derivatives and the degree of predictability of the meaning of such derivatives;

7. correctly describing the internal structure of nominal syntagms or groups in terms of the preciseness of testing which, primarily, includes basic or prototypical meanings derived from verbal stems, i. e., those that arise from synchronic word formation.

Our tests are based on occurrences with peculiar aspectual verbs, aspectual adjectives, and modifications by temporal adverbs or by temporal prepositions. We have compared and verified all of the examples cited in this article by consulting both native speakers' judgements and lexicographical sources. Comparing speaker information, grammar information, and lexicographical information is important in order to gain an understanding of the regularity of the lexical structure, i. e., the structure of event and agentive nominals.

We consider the lexical approach more appropriate because, as we said in the previous section, according to Chomsky, a pure syntactic approach to morphology complicates the description. This work is not, however, an argument for a lexical approach or against other types of theories. We only assume that the word formation and connected phenomena that we are interested in,

\footnotetext{
${ }^{15}$ In neuropsychological study by Shapiro, Shelton and Caramazza (2000), the result of patients RC and JR lead the investigators to the conclusion that access to specific grammatical properties associated with the category of verbs is independent of access to specific grammatical properties associated with the category of nouns (Caramazza/Romagno 2012: 44).

16 The idea that head $\mathrm{T}$ (ense) is precisely what distinguishes nominals from verbs is widely accepted by DM linguists (cf., e. g., Alexiadou 2001; Birtić 2008), but it has not been proven. It is a fact that in the nominal structure there is never a temporal morpheme, but the infinitive form of a verb also has no tense.
} 
nominalizations and the phrasal architecture of base verbs, may be more easily understood and described within a lexical theory than in others.

\section{The analysis of deverbal nouns in Slavic languages}

We will start our discussion with the word formation of event/process and agentive nominals in Slavic languages because in these languages the verb shows greater morphological complexity than it does in the Romance languages. The nominal inflectional system of the three Slavic languages examined here is rather rich: (a) they manifest morphological distinctions for three distinct grammatical genders (masculine, feminine and neuter) and two numbers ${ }^{17}$ (singular and plural); (b) they also display a full case system; (c) they are morphonologically marked for aspect and for Aktionsart; and (d) they each have a very large number of deverbal suffixes.

This subset of nouns has been extracted by taking into account morphological suffix productivity: a suffixing process is said to be productive if it is very general, i. e., if it affects a vast number of forms and creates very many words (cf. Aronoff/Anshen 2001). In this sense, the deverbal suffix -nje (Cro. and Slo.)/-anie (Pol.) is very productive, since a great majority of verbs can be turned into event nouns by this suffix.

In some cases, these Croatian suffixes correspond to the equivalent phonological forms in the other two languages, and in some cases those languages have different phonological forms with equivalent meaning and morphosyntactic behavior. Our examples are based on the content, not the phonological expression of that content $-i$. e., they are based on parallel clausal and nominal structures in the three languages.

The Croatian data we used here is from Babić's (1991) exhaustive monograph on word formation in the Croatian language. We compiled the Slovenian and Polish empirical data using two sources for each language: Bajec et al. (1980) and Toporišič (2000) for Slovenian, and Strutyński (2005) and Markowski/Pawelec (2007) for Polish. The event/process and agentive nouns are analysed according to their suffixes in Croatian (in alphabetical order). ${ }^{18}$ In some cases, these Croatian suffixes correspond to the equivalent phonological forms in the other two languages, and in some cases those languages have different phonological forms with equivalent meaning and morphosyntactic behavior. Our examples are based on the content, not the phonological expression of that content - i. e., they are based on parallel clausal and nominal structures in the three languages.

\footnotetext{
${ }^{17}$ In Slovenian there is a third number: dual (cf. Toporišič 2000: 206).

18 The Croatian linguist Matea Birtić published in 2008 her work about the formation of deverbal nouns in Croatian. She investigates morphology from the standpoint of current Distributed Morphology. We have benefited from her theoretical and descriptive studies. Grimshaw's approach differs from Birtićs with regard to seeing argument structure as a characteristic tied to lexical categories $\mathrm{N}$ and V. In her approach, the argument structure is conditioned by syntactic configuration and the presence of a verbal functional layer outside the root itself. Aspect, according to Birtić's description, represents the joining of an abstract root and three different aspect heads: $\mathrm{v}$, Perf, and Asp. According to Birtić such a description provides valid insight into the aspect morphology of Croatian verbs.
} 


\subsection{The analysis of event nouns in Slavic languages}

This section offers an analysis of event nouns in Croatian and compares Croatian nominalization patterns with analogous cases from Slovenian and Polish. We concentrate on the verbal properties of event nouns, and we present our own account of the internal structure of these nouns, which essentially relies on the presence of aspectual modifiers. In the following sections, we examine the event nominal formation applied to the same types of verbal stems with the same lexical results, but which may differ in their phonological forms - i. e., the phonological expressions of the suffixes are not necessarily identical in all these Slavic languages, but simply have parallel morphosyntactic behaviours.

To facilitate reading comprehension, we list the Slovenian and Polish deverbal event suffixes: a. Slovenian: -ø (skok), -aj (drhtaj), -ljaj (gibljaj), -ek (dogodek), -at (diktat), -ut (cvrkut), -v (odriv), -ěz (lajež), -a (zmaga), -ba (borba), -oba (žaloba), -enca (asistenca), -ija (korozija), -acija (adoracija), -ura (dresura), -arija (rezbarija), -nja (vožnja), -ava (izpeljava), -aža (montaža), -ezen (bolezen), -est (bolest), -av (ljubav), -itev (molitev), -nje (klanje), -anje (gibanje), -enje (pletenje), -tje (doživetje), -ilo (vračilo) (cf. Toporišić 2000); Polish: -anie (dodawanie), -enie (palenie), -cie (kopnięcie), -ka (wędrówka), -acja (prezentacja), -ø (chwyt), -a (mowa), -ba (prośba), -unek (ratunek), -ota (tęsknota) (cf. Wróbel 2001).

\subsubsection{The suffix $-a$}

This suffix ${ }^{19}$ can be attached to any verb form (perfective, imperfective, prefixed verbs, the verbal bases of all verb classes). ${ }^{20}$ Result and eventive interpretation often depends on context: Cro. isporuka 'delivery', isprika 'apology', odluka 'decision'. ${ }^{21}$ These nominals usually denote semelfactive action (a single act of V): Slo. dostava (not only semelfactive), opravičilo, odlok; Pol. dostawa, przeprosiny, decyzja.

As we have already noted above, the Croatian suffixes may differ from the Slovenian and Polish ones in phonological form: in these cases, the Croatian suffixation with $-a$ sometimes corresponds to suffixation with $-a$, and sometimes to zero suffixation, in the other two languages.

Eventive nominals may be formed from the same verbs by adding two different suffixes ( $-a$ and -anje): Cro. lupa/lupanje 'bang/banging'; Cro. kazna/kažnjavanje, Pol. kara/karanie, Slo. kazen/kaznovanje 'punishment/punishing'; Cro. rika/rikanje, Pol. rykø/ryczenie, Slo. rikø/rikanje 'roar/roaring'; Cro. pobjeda/pobjeđivanje, Slo. zmaga/zmagovanje, Pol. wygrana/wygrywanie 'win/winning'. 22

\footnotetext{
${ }^{19}$ In Slovenian and in Polish this suffix corresponds to the null suffix which forms masculine nominals, and the suffix $-a$ which forms feminine nominals.

${ }^{20}$ Croatian verbs are divided into six classes according to the infinitive ending and the rules for forming the present tense.

${ }^{21}$ This suffix is also productive in the formation of nomina instrumenti: Cro. braniti (Imperfective Asp) $\rightarrow$ brana (Instr); Slo. braniti $\rightarrow$ bran (Instr).

${ }^{22}$ As we have already noted above, the Croatian suffixes may differ from the Slovenian and Polish ones in phonological form: in these cases, the Croatian suffixation with $-a$ sometimes corresponds to suffixation with suffix $-a$, and sometimes to zero suffixation, in thr other two languages.
}

ISSN 1615-3014 
The shorter forms donote either durative or non-durative action, while the longer forms ending in -nje denote only durative action.

Consider the following examples containing such noun pairs:

(1) Cro. Dobava je trajala satima./Dobavljanje je trajalo satima.

'The provision took hours./The provisioning took hours.'

Lupa je trajala danima./Lupanje je trajalo danima.

'The bang lasted for days./The banging lasted for days.'

Rika je trajala cijelu noć./Rikanje je trajalo cijelu noć.

'The roar lasted all night./The roaring lasted all night.'

Slo. Dobava je trajala več ur./Dobavljanje je trajalo več ur.

Udar je trajal več ur./Udarjanje je trajalo več ur.

Ruk je trajal dolgo./Rukanje je trajalo dolgo.

Pol. Dostawa ciągnęła się godzinami./Dostarczanie ciągnęło się godzinami.

Hałas trwał dniami./Hałasowanie trwało dniami.

Ryk trwał całą noc./Ryczenie trwało całą noc.

These examples show that both of these deverbal noun forms can occur in the same context, i. e., they can be modified by the same adverbials: lupa/lupanje noću 'the bang/banging at night'; rika/rikanje danju 'the roar/roaring during the day'.

Deverbalized nouns ending in $-a$ indicate event/process, result or instrument nominals although their bases usually onsist of a perfective or transitive verbs. These nouns can also be pluralized: dobavljanja, lupanja, rikanja.

\subsubsection{The suffix $-a j$}

These nouns can be formed from all types of verbs (except those of type VI). They can be formed from perfective and imperfective verbs. All the nouns with this suffix can have eventive and result readings:

(2) Cro. ispraćaj $\mathrm{E}_{\text {(ventive) }}$ tijelaG $_{\text {(enitive) }}$ pok. fra LinićaG

'the funeral procession for the deceased Father Linić'

ŽeninPOSS ispraćaj $R_{\text {(esult) }}$ voljenog supruga

'the wife's funeral procession for the beloved husband'

inspektorov noćni izviđajE mjesta zločina

'the inspector's nocturnal investigation of the crime scene'

inspektorov izviđajR bio je učinkovit

'the inspector's investigation was effective'

Pol. odprowadzenieE ciała świętej pamieci brata Linića

odprowadzenieR ukochanego męża żony

nocne badanieE miejsca przestępstwa przez inspektora

badanie inspektora było skuteczne 
This is illustrated in Slovenian by the following examples: sprevod pokojnika 'the funeral procession for the deceased', nočna preiskava 'the nocturnal investigation', inšpektorjeva preiskava 'the inspector's investigation'.

Aspectual adjectives may occur as modifiers of nouns ending in -aj:

(3) Cro. Marijin neprestani/cjelonoćni/cjeloživotni vapaj

'Mary's constant/nightlong/lifelong wail'

Marijin vapaj noću; njen vapaj cijeloga života

pokojnikov popodnevni ispraćaj/pokojnikov ispraćaj popodne

'the afternoon funeral procession for the deceased/the funeral procession for

the deceased in the afternoon'

inspektorov izviđaj noću

'the inspector's investigation at night'

Pol. niekończący się/całonocny/dożywotni lament Maryji

jej lament całego życia; nocny lament Maryji

popołudniowe odprowadzenie zmarłego

nocne badanie inspektora

The equivalent Slovenian examples present a similar behaviour.

Nouns ending in $-a j$ also indicates semelfactive action ${ }^{23}$ (instantaneous; a single act of X): drhtaj 'a shudder' (Slo. drhtljáj, Pol. drżaczka), gucaj 'a gulp' (Slo. požirek, Pol. łyk, tykać), izdisaj 'an exhalation' (Slo. izdih, Pol. wydech), jecaj 'a sob' (Slo. jok, Pol. jęk, jęczenie) koračaj 'a step' (Slo. koračaj, korak), kucaj 'a knock' (Slo. trk, Pol. puknięcie), poticaj 'a stimulus' (Slo. dražljaj, spodbuda, Pol. wsparcie), vapaj 'a wail' (Slo. jok, Pol. lament), posrtaj 'a stumble' (Slo. spotikljaj, spotik). But mostly they can be neutral depending on the context (above, we illustrated three examples with the noun vapaj):

Cro. česti poticaj države/često poticanje države

'frequent stimulus/frequent stimulating of the state'

poticaj u 4 etape/poticanje u 4 etape

'4-stage stimulus/4-stage stimulating'

Pol. częste wsparcie Państwa/częste wspieranie Państwa wsparcie w 4 etapach/wspieranie w 4 etapach

According to Distributed Morphology, these nouns are not event/process nominals. However, some nouns ending in - aj behave like event/process nominals. Our analysis shows that adverbial modifiers do not always reveal the eventivity/processuality of nouns because their property of eventivity differs (i. e., they are distinct in nature) from verbal eventivity (Cro. Marijin vapaj noću 'Mary's wail at night'/Marija vapi noću 'Mary wails at night' = Marijin noćni vapaj 'Mary's night wail'; Pol. Maryji lament/krzyk noca/Maryja lamentuje/krzyczy noca = Maryji lament/krzyk noca).

\footnotetext{
${ }^{23}$ Nouns in -ada also indicate semelfactive action (instantaneous) but they are formed from diaspectual verbs: blokada, rošada (Slo. blokada, rošadalrokada; Pol. blokada, roszada).
} 


\subsubsection{The suffix $-a k$}

These nouns are fromed all types of verbs (except those of type VI), but mainly from perfective verbs (prefix verbs). They have result, eventive and instrumental meaning: Cro. pljesnuti $\mathrm{P}_{\text {(erfec- }}$ ${ }_{\text {tive) }} /$ pljeskatiI (mperfective) 'to slap/to applaud' $\rightarrow$ pljesak 'applause', česti pljesak 'frequent applause'; ${ }^{24}$ Slo. ploskniti/ploskati $\rightarrow$ plosk, pogosti plosk; Cro. prasnutiP/praskatiI 'to detonate (once)/to detonate (multiple times)' $\rightarrow$ prasak 'detonation', česti/dugotrajni prasak 'frequent/lengthy detonation'; Slo. treskniti/treskati $\rightarrow$ tresk/pogosti tresk.

Nominals with the suffix $-a k$ are formed from transitive and intransitive verbs. These derived forms are characterized by the following argument structure:

(5) Cro. Ivanov kratki boravak u Bernu/Ivanov boravak od dva sata.

'Ivan's brief stay in Bern/Ivan's two-hour stay.'

Lukin ispravak $(\mathrm{Tr})$ zadaće u pola sata

'Luka's half-hour homework correction'

Mariov izlazak za sat vremena/Mariov česti izlazak/Mariovi česti izlasci

danju

'Mario's going out in an hour/Mario's frequent going out/Mario's frequentgoings out during the day'

Slo. Ivanovo kratko bivanje v Bernu. Ivanovo dveurno bivanje

Lukovo popravljanje naloge $\mathrm{v}$ pol ure/Lukov popravek naloge $\mathrm{v}$ pol ure

Marijev izhod za eno uro/Marijev pogost izhod/Marijevi pogosti dnevni izhodi

Pol. krótki pobyt Iwana w Bernie/dwugodzinny pobyt Iwana

poprawienie Łukaszowego zadania w pół godziny

wyjście Maria za godzinę/częste wyjście Maria/częste wyjścia Maria w

dzień

The behaviour of these nominals is as illustrated regardless of the verb type (perfective, imperfective, unergative, unaccusative) ${ }^{25}$ Mostly these nouns can be modified by an aspectual adjective or an adverb, but from the point of view of native speakers (who are not professional linguists), some of the linguistic constructions above are not natural; in fact, they consider these constructions quite artificial. Native speakers typically consider the construction with the argument in the genitive case and in the plural to be more natural: dolasci $\mathrm{P}_{(\text {lural }}$ mladeži satima; ispravciP zadaća danima; polasciP vlakova noću etc. Plural implies iterativity/imperfectivity, while singular, on the contrary, implies semelfactivity (cf. Alexiadou 2001): Cro. sunce je zašlo u pola sata = zalazak sunca $u$ pola sata 'the sun went down in half an hour = the sundown in

\footnotetext{
${ }^{24}$ For example: Česti pljesak prekidao je predsjednikov govor. 'Frequent applause interrupted the president's speech.'

${ }^{25}$ Here are some other interesting examples: Cro. postanak svijeta $u$ sedam dana 'the origin of the world in seven days'; opstanak ljudske vrste u sljedeća dva stoljeća 'the survival of the human race in the next two centuries'; Markov višesatni rastanak od obitelji 'Mark's hours-long parting from his family'; Markov dugi rastanak od roditelja 'Mark's long parting from his parents'; Pol. poczatek świata $w$ siedem dni; przetrwanie rasy ludzkiej $w$ ciagu następnych dwóch stuleci; kilkugodzinne rozdzielenie Marka od rodziny; dlugie rozdzielenie Marka od rodziców.
} 
half an hour'; Slo. sonce je zašlo v pol ure = sončni zahod v pol vure; Pol. stońce zaszło $w$ pót godziny = zachód stońca $w$ pót godziny; Cro. prešao je livadu u sat vremena = prelazak livade $u$ sat vremena 'he crossed the meadow in an hour = the crossing of the meadow in an hour'; Slo. prehod travnika $v$ eni uri $=$ prehodil je travnik $v$ eni uri; Pol. przeszedt take $w$ godzine $=$ przejście łąki w godzine.

\subsubsection{The suffix $-b a$}

This can be attached to perfective and imperfective, transitive and intransitive verbal bases. The suffix - $b a$ mainly indicates verbal action (event/process nominals), but also result nouns: ${ }^{26}$

(6) Cro. Ivanova stalna berba grožđa/berba grožđa noću

'Ivan's constant grape harvesting/grape harvesting at night'

Ivanova neprestana borba danju i noću

'Ivan's incessant struggle during the day and night'

Lukina izobrazba u 4 godine

'Luka's education in four years'

Pol. stały zbiór winogron Jana/nocny zbiór winogron

ciągła walka Jana dniami i nocami

wykształcenie Łukasa w 4 lata

Slo. Ivanovo stalno trganje grozdja/trganje grozdja ponoči

Ivanov neprestani boj podnevi in ponoči

Lukovo izobraževanje $\mathrm{v}$ štirih letih

In such cases it is also difficult to show that there are eventive structures in these nouns (with the test of eventivity). There is systematic result/eventive ambiguity, and it is impossibile to have eventive reading only. Even when these nominals denote eventivity, they can be pluralized: borbe, berbe.

\subsubsection{The suffix -će}

The nouns in -će are derived from past participle:

$$
\begin{aligned}
& \text { Cro. začet }+ \text { je } \rightarrow \text { začeće 'conception' } \\
& \text { otkrit }+ \text { je } \rightarrow \text { otkriće 'discovery' } \\
& \text { izuzet }+ \text { je } \rightarrow \text { izuzeće 'exemption' }
\end{aligned}
$$

$$
\begin{array}{ll}
\text { Pol. } & \text { poczęty - poczęcie } \\
\text { odkryć - odkrycie } \\
\text { wyłączenie - wyjąątek }
\end{array}
$$

Mostly these nouns can be modified by an aspectual adjective or an adverb: Cro. doktorovo ljetno otkriće lijeka 'doctor's summer discovery of medicine'/Ivanovo otkriće ljeti 'John's discovery during the summer'/doktorova stalna otkrića lijekova ljeti 'the doctor's constant summer discoveries of drugs'; BorninoObject začeće noću 'Borna's(Object) conception during the night'/Marijinosubject začeće noću 'Mary's(Subject) conception during the night'; Markovo izuzeće

\footnotetext{
${ }^{26}$ In Croatian, adverbials can occure with result nouns: Ivanova uknjižba ujutro 'Ivan's registration in the morning'. But in constructions of this type, we are in effect dealing with elliptical constructions: Ivanova uknjižba (dogodila se) ujutro 'Ivan's registration (happened) in the morning'.
} 
bilo je u tijeku kada je reagirao šef 'Mark's exemption was in progress when the chief reacted'; Pol. lekarskie letnie odkrycie leku/otkrycie Jana latem/trwałe lekarskie odkrywanie leku.

From these examples we can see that result nouns ending in -će can behave like eventive nouns, even though we are dealing with simple event and result nominals derived from perfective, intransitive and unaccusative verbs.

\subsubsection{The suffix - nje}

This suffix primarily indicates an event/process. Its meaning depends on the properties of the verbal base: the output of an imperfective or a "diaspectual" verb is a durative event; the output of a perfective verb is a non-durative event noun, a result noun or an object.

Nominals with the suffix -nje commonly come in aspectual pairs: ${ }^{27}$ ukliještenje/uklještavanje; poništenje/poništavanje; iskupljenje/iskupljivanje, iskušenje/iskušavanje, istrebljenje/istrebljivanje, dokinuće/dokidanje, sahnuće/usahnuće. These nominals may also take plural forms.

All these pairs can occur in the same context:

(8) Cro. njegovo iskupljenje/iskupljivanje trajalo je godinama

'his redemption took years'/'he was redeeming himself for years'

Pol. jego odkupienie/odkupywanie trwało latami

We can corroborate the above assumption with a few more Croatian examples: konstantno iskušenje/iskušavanje Ivana 'John's constantly temptation', Ivanovo sporo poništenje/poništavanje odluke/a 'John's slow annulment of decision(s)', Ivanovo često poništenje/poništavanje odluke/a 'John's frequent annulment of decision(s)'.

Nouns derived from perfective bases behave in the following way: Cro. to je bilo Markovo poslanje cijeli život/to je bilo njegovo životno poslanje 'this was Mark's mission his whole life/this was his life's mission', Pol. to była misja życia Markalto była misja jego życia; Cro. Ivanovo stalno pouzdanje u ljudsku dobrotu 'John's constant belief in human goodness', Pol. stałe zaufanie ludzkiej dobroci Jana. ${ }^{28}$ These examples show that the verbal base feature [+perfective] can be neutralized.

It is interesting note that, unlike Romance languages, Slavic languages, have transitive nominalizations, which are excluded from DM theory (cf. Alexiadou 2001: 77): Mariovo darivanje sestre/Ivanovo kupovanje dara 'Mario's giving of presents to his sister/Ivan's purchasing of the present'.

\footnotetext{
27 The place of accent can also denote the different aspects of derived nouns: pèčènje/pečénje; ìmānje/imánje; kř̌stēnje/kršténje; vjènčānje/vjenčánje; ïmenovānje/imenovánje; poštòvānje/poštovánje; putòvānje/putovánje etc. The first example in each pair above denotes a result nominal and the second example in each pair above denotes an event nominal.

28 There are many of these nouns: Cro. predati se $\rightarrow$ predanje; Pol. oddać się $\rightarrow$ oddanie, oddawanie; Cro. Ivanovo predanje svome poslu godinama; Pol. oddanie Jana swojej pracy latami 'Ivan's devotion to his job for years' etc.
} 


\subsubsection{The suffix -ost}

These nominals are formed from adjectives and adjectival participles. The outputs of this formation are abstract nouns indicating some kind of state, i. e., state nouns. The suffix -ost shows that in analysed Slavic languages there is a suffix that can nominalize over the external aspect of the verb; in these cases, the nominalization can denote aspectual notions not contained in the base's actionality: Cro. trotjedna poplavljenost Slavonije 'the three week flooding of Slavonia'; trodnevna budnost građana 'the citizens' three-day wakefulness', trosatna brbljavost govornika 'the speaker's three-hour chattiness'. The verbal bases poplaviti, buditi, brbljati do not contain a state component. This type of word formation exists also in Slovenian (štiriletna uničenost Zadra 'Zadar being destroyed for four years', triurna brbljavost govornika 'the speaker's three-hour chattiness') and Polish (trzygodzinna gadatliwość mówcy 'the speaker's three-hour chattiness', czteroletnia zniszczalność miasta 'a town being destroyed for four years'). In contrast, in Spanish, French and Italian, verbal suffixes cannot be introduced so late in the structure; they can only build over the information internal to the verbal phrase (cf. Fábregas and Marín 2012).

\subsubsection{The zero suffix}

Nominals with the zero suffix derive from perfective, imperfective, transitive and intransitive verbs (dodirnuti 'to touch' $\rightarrow$ dodir 'a touch', pokliknuti 'to exclaim' $\rightarrow$ poklik 'an exclamation', dočekati 'to receive' $\rightarrow$ doček 'a reception', hukati 'to roar' $\rightarrow$ huk 'a roar'). Some of these nominals are ambiguous in that they can have eventive and result readings. This often depends on the property of the verbal base. Zero-suffix nominals allow an argument structure even when they express a semelfactive action, as in the following examples: studentov doček prijatelja 'the student's welcome of his friend'; ${ }^{29}$ huk valova noću 'the roar of the waves at night'. The agentive noun pribjeg 'refugee' is derived from the unaccusative verb pribjeći.

\subsection{The analysis of agentive nouns in Slavic languages}

\subsubsection{The suffix $-a \check{c}$}

In Croatian, the suffix - $a c$ forms agentive nouns from non-perfective verbs in the vast majority of cases (93\%; Babić 1991: 244). The same phonological forms exist in Slovenian (dobavljač, prihajač) and in Polish (kopacz, sprzatacz). In Slovenian, however, the equivalent suffixes -ik and $-e c$ are used more often.

Agentive nouns derived from perfective verbs are not sensitive to perfectiveness, that is, their internal structure does not involve Aspect.

(9) Cro. potrošač, opažač, ponuđač

'consumer, perceiver, bidder'

\footnotetext{
${ }^{29}$ According to Birtić (2008: 166), this example is ungrammatical because both arguments can represent a potential object of action. We argue, however, that this syntactic construction can normally be interpreted to mean that 'student(subject/external arg.) welcomes his friend(object/internal arg.)'.
} 
Slo. potrošnik, opazovalec, ponudnik

Pol. konsument, obserwator, usługodawca

In Slovenian, these nominals also derive from perfective verbs, while in Polish, they derive from aspectually neutral verbs.

It is possible to interpret these nouns as perfective: at the precise moment, when a person performs the action, he/she is a potrošač, opažač, ponuđač ('consumer, perceiver, bidder').

Agentive nominals ending in - $a \check{c}$ can be derived from transitive and intransitive verbs, but they are almost solely derived from unergative verbs. The argument of an unergative verb is located in the subject position, while the argument of an unaccusative verb is located in the object position, as is the object of a transitive verb. In Croatian, the exceptions to this pattern of agentive formation with the suffix $-a c$ include two verbs: padati $\rightarrow$ padač 'faller' (unaccusative), smijati se $\rightarrow$ smijač 'laugher' (unaccusative). The correspondent suffix is not possibile in these cases in other languages: It. ${ }^{*}$ caditore, Fr. ${ }^{*}$ tombeur, Sp. ${ }^{*}$ caidor; It. *ridetore, Fr. rieur, Sp. reidor, Slo. smejavec, Pol. śmieszek). This is interesting because the verb smijati se ('to smile/to laugh') is agentive in meaning (syntactically unergative). If we test the verbs with their participles (present and past participles), we can see that the participles can be used: Cro. $n_{a s m i j a n i}$ (p.p.) dječak 'laughing boy', Slo. nasmejani( $i_{\text {(p.p.) }}$ deček, smejoči (pr.p.) deček; It. un ragazzo sorridente(pr.p.). It is well known that the participle of a transitive verb in adjectival function cannot relate to a subject, but only to an object. This is because the subjects of unaccustive verbs, but not those of unergative verbs, share the syntactic and semantic properties of the direct objects of transitive verbs. The single arguments of unaccusative verbs and the objects of transitive verbs are all underlying objects, which cannot assign Case to the subjects. This means that the subject of transitive and unergative predicates cannot be modified by participles (paste or present). In Italian, all nouns derived from unaccusative verbs permit participles modifying nouns, while those derived from unergative verbs do not permit them: una nave affondata 'a sunken ship', uno studente laureatosi un anno fa 'a student who graduated a year ago', un ospite arrivato da un ora' 'a guest that arrived an hour ago'. ${ }^{30}$

In the Croatian language, only participles formed from prefixed verbs (with very few exceptions) can have adjectival function: *došli uzvanici/pridošli uzvanici 'guests that have arrived'; Slo. prihajali povabljenci, Pol. przybyli goście, It. gli ospiti arrivati, Fr. invités arrivés, Sp. huéspedos llegados. Why may we use only participles of prefixed verbs? Probably because the past participle form is inherently perfective in Romance languages, while in Slavic languages that property is mostly located in prefixes.

It can be concluded that the verb smijati se 'to laugh' is unaccusative in Croatian, in Polish, and in Slovenian and unergative in English and in Romance languages. The question then arises as to why this is the case. ${ }^{31}$

\footnotetext{
${ }^{30}$ Similarly, in French there is perfect participle agreeement with unaccusatives but not with unergatives.

${ }^{31}$ In Slavic and in Romance languages the majority of semantically equivalent verbs belong to the same verbal type (unergative/unaccusative): šetač (It. passeggiatore), skakač (It. saltatore), spavač (It. dormiente) etc. However, there are also some differences, e. g. the verb allenarsi 'to train' in Italian is unaccusative, while the equivalent Croatian verb vježbati is unergative, the Italian verb passare 'to pass' is unergative, while the equivalent Croatian verb proći is unaccusative.
} 
In DM, the inability to form nominals from unaccusative verbs and agentive interpretation are considered to be indisputable indicators of the presence of the verbal functional layer in the internal structure of nominals (cf., e. g., Alexiadou 2001; Birtić 2008). But, as we will see in the next paragraphs, there are a certain number of exceptions.

Unlike verbal clauses, these nominals do not allow adverbial modification:

(10) Cro. trčati jutrom/*trkač jutrom

krojiti noću/*krojač noću

nabavljati često/*nabavljač često

The aspectual adjectival, on the contrary, can be used with agentive nouns: jutarnji trkač 'morning runner', noćni krojač 'nocturnal tailor', česti nabavljač 'frequent supplier'; Slo. jutranji tekač, nočni krojač, pogosti dobavitelj. Pol. biegacz rannyì, krawiec nocny, dostawca częsty; Alexiadou (2001) presupposes that it depends on the functional category of Number (NumP). Why is the aspectual adjective čest 'frequent' possible with nouns nabavljač and trkač, but not possible with krojač? This point may be clearer when addressed from another perspective. That is, it can depend on the semantic properties of verbal bases which are compatible/incompatible with the meaning of the agentive noun in question: krojač 'tailor' denotes an occupation from which follow that it has features of durativity (constantness). Therefore, the reasons for such behaviour of some agentive nouns are extralinguistic.

Some agentive nouns ending in - $a c ̌$ inherently contain adverbial modification: Cro. psovač 'person who swears frequently, and readily/willingly', Slo. psovalec, bogokletnik, Pol. przeklinacz; Cro. opažač 'person who describes frequently, and readily/willingly', Slo. opazovalec, Pol. obserwator.

Nominals ending in - $a \check{c}$ can be interpreted either as Agent or as Instrumental. This ambiguity sparked a discussion on thematic marking in language structure. Specifically, we were curious as to whether there is a relationship between perfectiveness and instrumentality. Our data show that there is no such narrow relationship. The following examples illustrate the formation of agentive/instrumental nouns from imperfective predicates:

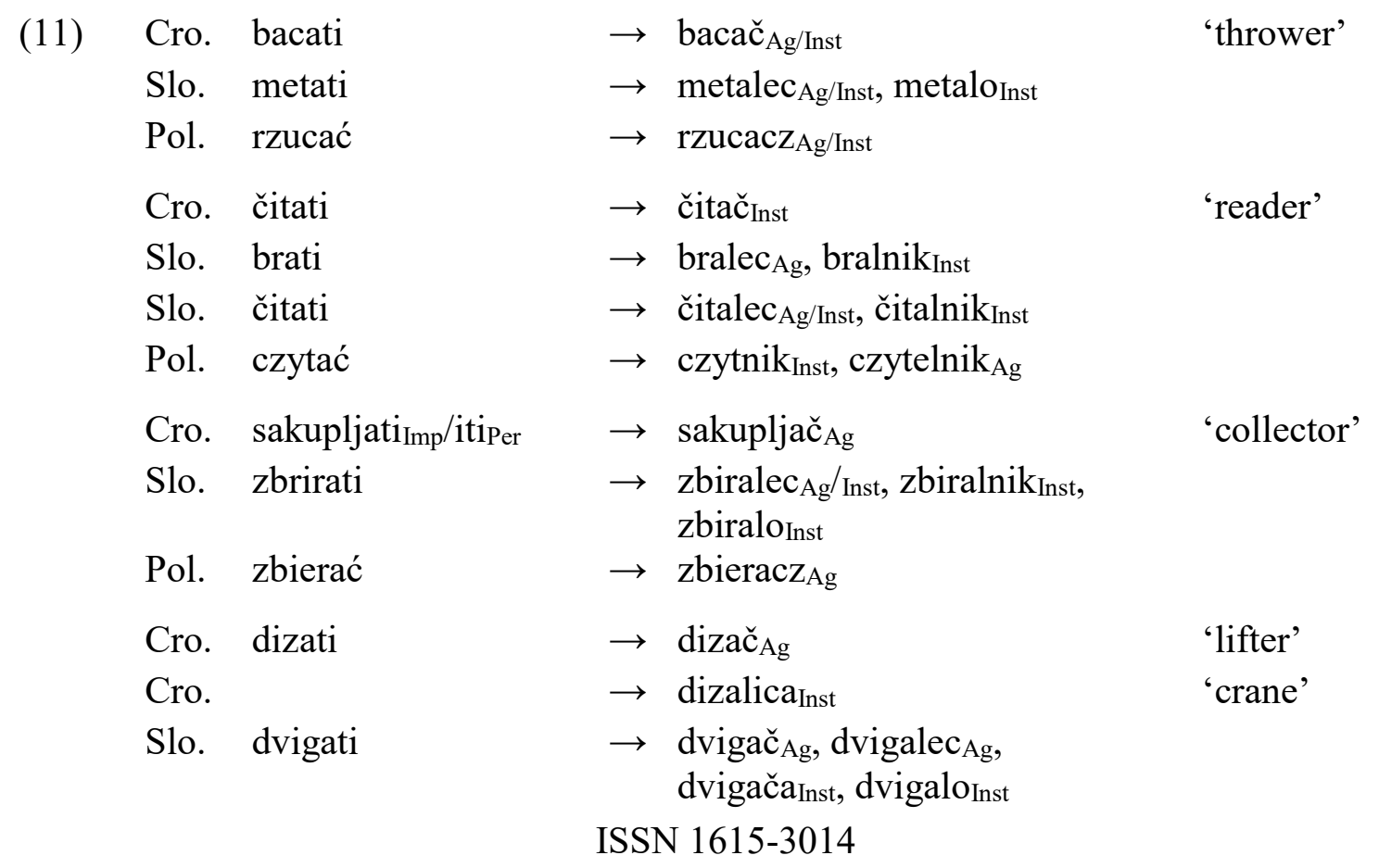


Pol. podnosić $\rightarrow$ podnosacz $\mathrm{Ag}$, podnośnik Inst

Looking at these cases, we see that the suffix determines the semantic type (interpretation) of nominals (Inst or Ag). This type of nouns has many examples in all these languages.

Let us look at the following pairs of synonyms in Croatian:

\begin{tabular}{|c|c|c|}
\hline Cro. & isprašač - isprašivač & 'carpet-beater' \\
\hline & izvikač - izvikavač & 'crier' \\
\hline & rasprskač - rasprskivač & 'atomizer' \\
\hline & ugnjetač - ugnjetavač & 'oppressor' \\
\hline & utemeljač - utemeljivač (utemeljitelj) & 'founder' 32 \\
\hline
\end{tabular}

For each of the pairs listed in (12), the first example (on the left) was created from perfective predicates, while the second (on the right) was created from an imperfective predicate. But they are in fact synonyms. They formally express an aspectual category but this fact doesn't influence the semantic-syntactic behaviours of these words. The question of the relationship of the aspect marker of the stem to the possible interpretation of the nominal is difficult to solve. An interrelation between imperfectiveness of the stem and agentive, active and event interpretation is widely noted, as well as between the perfectiveness of the stem and the result interpretation, but in Slavic languages such an interrelation is not a regularity. In agentive nominals their inclination towards combining with imperfective stems is emphasized; in Croatian, for example, two very productive agentive suffixes (-telj and -nik; the first is even the most productive) can be attached in equal measure to perfective and imperfective verbs.

To distinguish between agentive and instrumental nouns, Slavic languages can use different suffixes:

$\begin{array}{lllll}\text { Cro. } & \text { pekar }_{\mathrm{Ag}} & \text { 'baker' } & \begin{array}{l}\text { pekač Inst } \\ \text { pekač Inst }\end{array} & \text { 'bread maker' } \\ \text { Slo. } & \text { pek }_{\mathrm{Ag}} & & \begin{array}{l}\text { piekaczInst, piekarnik } \\ \text { Inst }\end{array} & \\ \text { Pol. } & \text { piekarz }_{\mathrm{Ag}} & & \text { 'printer' } \\ \text { Cro. } & \text { pisac }_{\mathrm{Ag}} & \text { 'writer' } & \begin{array}{l}\text { pisač Inst } \\ \text { pisak }^{33}\end{array} & \\ \text { Pol. } & \text { pisarz } & & \text { 'digital reader' } \\ \text { Cro. } & \text { čitatelj } & \text { 'reader' } & \text { čitač } & \\ \text { Slo. } & \text { bralec } & & \text { bralnik } & \\ \text { Pol. } & \text { czytelnik } & & \text { czytnik }\end{array}$

In this case, the suffixes function with precise semantic content: the relationship between the suffixes and verb stems is one-to-one.

\footnotetext{
32 We did not find such examples in Polish or in Slovenian.

${ }^{33}$ In Slovenian, pisec means 'writer', but pisač is 'scribe', while 'printer' is tiskalnik.
} 


\subsubsection{The suffix $-i k$}

Deverbal nominals suffixed with $-i k$ are formed in large part from the passive participle: ${ }^{34}$ branjenik 'client' uzvanik 'invited person' (Slo. vabljenec), blaženik 'blessed person', (Slo. blaženec), slavljenik 'feted person' (Slo. slavljenec), namještenik 'employee' (Slo. zaposlenec), izabranik 'chosen person' (Slo. izbranec) etc.

These nouns can be modified by aspectual adverbs; the same is true of nouns created from adjectives: dužnik, česti dužnik, vječni dužnik bankama, 'debtor, common (repeated) debtor, eternal debtor to the banks', Slo. dolžnik, pogosti dolžnik, večni dolžnik bankam; Pol. dtużnik, częsty dtużnik, staty dtużnik w banku; razvratnik, on je često razvratnik 'philanderer, he is often a philanderer', Slo. razuzdanec, Pol. rozpustnik, on jest czessto rozpustnik. They are created from perfective and imperfective verbs: hapšenik/uhićenik 'detainee' (Slo. aretiranec, Pol. aresztowany). These nouns include derivatives with passive meaning and with the meaning of the reflexive verb. For instance, iseljenik is a person who has moved out voluntarily or nonvoluntarily; osuđenik 'convict', utopljenik 'drowned person', zaljubljenik 'enthusiast', zatvorenik 'prisoner' etc.

The variant - $\boldsymbol{n i k}$ forms agentive nominals equally from perfective and imperfective verbs (also from other major lexical categories). These nominals can have passive and active meanings: patnik 'sufferer', izvoznik 'exporter'. It is interesting that they may also be formed from unaccusative verbs: Cro. dolaznik, Pol. przybysz 'comer'; Cro. prolaznik, Pol. przechodzień 'passerby'.

\subsubsection{The suffix -telj}

This suffix can make the agentive nouns from perfective, imperfective, transitive and intransitive verbs, but all these agentive nouns have the same semantic paraphrase: $V+$ telj "one who $\mathrm{V}_{\text {present" }}$ (habitually, professionally).

The left member of the following pairs is created from perfective (or non-durative) verbs, and the other from imperfective verbs: utješitelj/tješitelj 'consoler' (Pol. pocieszyciel/cieszyciel); graditelj/dograditelj 'builder, constructor' (Pol. budowniczy/budowniczy dobudówki); ispunitelj/ispunjavatelj; obranitelj/branitelj 'one who succeed in defending/defender (advocate)', obratitelj/obraćatelj; odgojitelj/odgajatelj 'educator'; krotitelj/ukrotitelj 'tamer'; miritelj/izmiritelj 'conciliator'. ${ }^{35}$

The aspect is neutralised in the following cases:

Cro. izvršitelj: onaj koji izvrši/onaj koji 'executor: one who executes'
izvršava

\footnotetext{
${ }^{34}$ In Italian these nouns are formed by conversion of the past participle: difeso, invitato, beato, festeggiato, impiegato, eletto.

35 These noun pairs do not behave consistently: Zločinac je umorioPerf tri djevojčice 'A criminal has killed three little girls' but there is moriteljImp triju djevojčica 'killer of three girls' and not umoriteljPerf, although the latter nominal is not wrong. Similary, in Polish we have Złoczyńca zamordowat trzy dziewczynki, whereas * zamorderca trzech dziewczynek is not possible, although (za)mordować/morderca trzech dziewczynek is acceptable.
} 


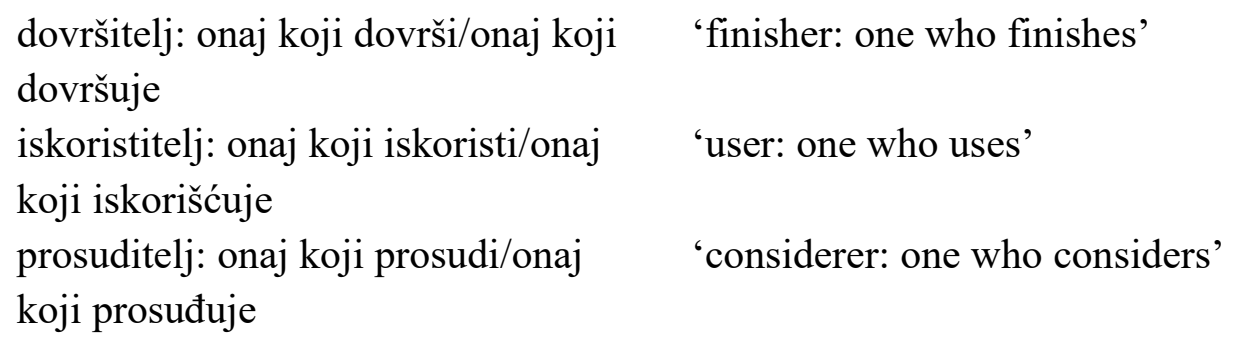

It is the same in Polish: wykonawca, wykończyciel, wykorzystywacz etc.

There is not a difference in meaning between the agentive suffixes -telj and $-l(a) c$ : slušatelj/slušalac, gledatelj/gledalac but they are distinguished by their distribution. Interestingly enough, these synonymous agentive nouns have an important difference in their distribution: nouns ending in -lac are mostly derived from imperfective verbs, whereas nouns ending in -telj are derived slightly more often from perfective verbs.

There are the pairs denoting agent (in -telj) vs. patient (in -ik): branitelj-branjenik 'defender (advocate) - client'; progonitelj - progonjenik 'persecutor - persecuted person' uvreditelj uvređenik 'offender - offended person' etc. Pol. obrońca - broniony, prześladowca prześladowany, obraziciel - obrażony.

Nouns that denote patient are formed by the suffix -nik/ik, which is added to past participles. From DM theory (cf. Birtic 2008) it follows that their structure under the vP is the same as it is in agentive nouns (Asp and Perf under vP). In other words, patient nouns are distinguished from agent nouns only in terms of one characteristic: agent nouns project SpecvP, while patient nouns do not project SpecvP. According to Birtić (2008: 175), the problem is that some patient derivatives contain a passive participle in their structure - a passive participle which is presumed to have a structure that includes AspP-vP. In other words, the vP projects the specificator. There is no agent noun that has a passive participle in its structure. Therefore, it is presumed that the light verb $\mathrm{v}$ in the structure of the passive participle does not have SpecvP.

Let us now turn our attention to -telj. This suffix illustrates how the nominalizations may neutralize the aspect of perfective and imperfective nouns. All these nouns, regardless of aspect, behave in the same mode: uzgojitelj/uzgajatelj 'cultivator', odgojitelj/odgajatelj 'educator', izlječitelj/liječitelj 'healer', e. g., Svakog se mjeseca javlja neki novi odgojitelj/odgajatelj naše djece 'Every month some new educator of our children appears'.

\subsection{Formations from prefixed verbs that express Aktionsart}

Up to now we have analysed the properties and behaviour of deverbal nominals regarding mainly the perfectiveness/imperfectiveness of verbal bases. In this section we will study in some detail deverbal formations related to verb actionality (Aktionsart).

Aspect implies a particular way of seeing an action and reflects the subjective perception of the speaker. It is usually expressed grammatically. Aktionsart defines the nature of the verbal process, indicating the manner of the evolution of that process, the objective mode of realization of the process out of the point of view of the speaker. It is expressed through the lexical form inherent to the verb or by the mechanisms of derivational morphology. Imperfective verbs are not all imperfective/nonterminative in the same way, and even the perfective/terminative ones 
are not all perfective in the same way, but they differ in the manner of the development of verbal action as the lexical meaning of the verb. This is Aktionsart. The classification of verbs according to the manner of the development of verbal action is evident in the inherent semantic value of the verbal lexeme and in certain word-formation categories, as well as in morphosyntactic relations. The actional characteristics of a verb are usually defined by the semantic features of durativity, dynamicity, telicity etc. And so there is an opposition between durative and nondurative events, eventive vs. stative verbs. In summary, in modern linguistics there is a widespread distinction between aspect, as a syntactic and grammatical category, and actionality, which is considered a lexical category related to the semantic classification of verbs and derivational morphology (cf. Bertinetto/Delfitto 2000; Fowler 1996; Birtić 2008; among others).

The Slavic languages generally provide morphological realizations of Aspect and Aktionsart, while the Romance languages use mainly the tense system for the expression of Aspect and the Actionsart is usually contained in the lexical item. Prefixes and imperfective suffixes in the Slavic languages represent divided projections in the functional structure of the sentence (cf. Fowler 1996) because Actionsart prefixes introduce additional non-aspectual meaning to the verb content, i. e., in Slavic languages, the additional semantic shades (or connotations) of perfectivity, such as resultativity, inchoativity etc. are expressed by prefixes, while the imperfective shades are usually a part of the semantics of the lexeme (Cro. buditi $i_{\text {durative }} /$ probudit $i_{\text {non-durative }}$

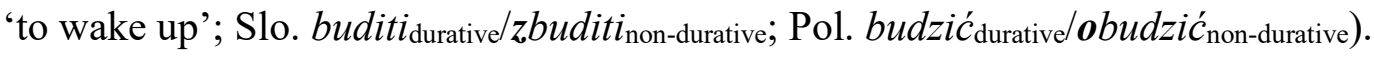

The verbal aspect is expressed by the perfective/imperfective opposition. Perfective aspect indicates an action seen as totality. Imperfective aspect leaves this feature unbounded/nonterminative, i. e., the action is seen as in process, regardless of the beginning and the end. Verbs containing one kind of aspect usually have a counterpart with the other aspect with the same lexical meaning, and they represent an aspectual pair/opposition: Cro. dati $i_{\text {perfective/davat }} i_{\text {imperfec- }}$ tive 'to give'; Slo. kupiti/kupovati 'to buy'; Pol. dać/dawać 'to give', kupić/kupować 'to buy'. Perfectivization in Slavic languages is achieved by prefixal and suffixal word formation: Cro. raditi/uraditi 'to work', sići/silaziti 'to get down'. In Romance languages, this is achieved by verbal tensesas we mentioned above). There are also biaspectual verbs, i. e. aspectually neutral verbs, e. g. Cro. cjelivati 'to kiss', definirati 'to define', žrtvovati 'to sacrifice'.

The formation of agentive and event nominals from almost all types of non-durative verbs in Croatian, Slovenian and Polish is unproductive if there is an intention to mantain non-durative Aktionsart, whereas it is mostly possible if the noun expresses durative Aktionsart. Non-durative actionality is indicted by the prefix.

I. non-durative verbs

a) inchoative verbs: hodati 'to walk' $\rightarrow$ hodanje, hodač; prohodati 'to begin walking' $\rightarrow$ *prohodač, *prohodanje; Slo. hoditi $\rightarrow$ hod, hodec; prehoditi $\rightarrow$ prehod, *prehodec; Pol. Chodzić $\rightarrow$ chodzenie, chodacz, chodziarz ('racewalker'), *zachodacz

b) delimitative verbs: poigrati se 'to play with' $\rightarrow$ *poigranje, *poigrać; Slo. poigrati $s e \rightarrow$ *poigrač; Pol. pograć $\rightarrow$ *poigracz

c) telic verbs: odletjeti 'to fly away' $\rightarrow$ odletaj, *odletač; Slo. odleteti $\rightarrow$ odlet, *odletec; Pol. przylatywać, odlatywać $\rightarrow$ odlot, *odlatywacz 
d) terminative verbs: probiti 'to break through' $\rightarrow$ proboj, ? probijač. ${ }^{36}$ Slo. prebiti $\rightarrow$ preboj, ?prebijač; Pol. przebić $\rightarrow$ przebicie, *przebiwacz

e) subject-distributive verbs: poskakati 'to jump into' $\rightarrow$ *poskakaj, *poskakač, Slo. Poskakati $\rightarrow$ *poskak, *poskakec; Pol. podskoczyć $\rightarrow$ podskoczenie, *podskoczywacz

f) object-distributive verbs: pobacati 'to throw away' $\rightarrow$ *pobacanje, *pobacač, Slo. Pometati $\rightarrow$ *pometanje, *pometnik; Pol. rozrzucać $\rightarrow$ rozrzucanie, ?'rozrzucacz

g) semelfactive (one single act): zijevnuti 'to yawn' $\rightarrow$ zijev, ${ }^{*}$ zijevnuč; Slo. zevniti $\rightarrow{ }^{*} z e v$, $*_{z e v n i k ;}$ Pol. ziewnąć $\rightarrow$ ziewnięcie, *ziewnięcacz

When the distinction between durative and non-durative verbs depends on the prefix, the behaviour of these nouns is different than in the cases when we are dealing with a suffix-conditioned distinction.

However, in Croatian there is a set of deverbal agentive nouns which are derived from nondurative verbs: uzgojiti 'to cultivate' $\rightarrow$ uzgojitelj, dograditi 'to build an extension' $\rightarrow$ dograditelj, dopuniti 'to update' $\rightarrow$ dopunitelj, dovršiti 'to complete' $\rightarrow$ dovršitelj, izgovoriti 'to utter' $\rightarrow$ izgovoritelj (cf. Babić 1991: 294).

II. durative verbs

a) iterative verbs: noćivati 'to stay overnight' $\rightarrow$ noćivanje, noćivatelj; Slo. Nočevati $\rightarrow$ nočevanje, nočevalec; Pol. nocować $\rightarrow$ nocowanie, nocowacz; Cro. večeravati 'to have dinner' $\rightarrow$ večeravanje, ${ }^{*}$ večeratelj; Slo. večerjati $\rightarrow$ večerja, ${ }^{*}$ večerjalec $^{37}$

b) evolutive verbs: venuti 'to wilt' $\rightarrow$ venjenje; Slo. veniti $\rightarrow$ venenje; Pol. Zwiędnąć $\rightarrow$ zwiędnięcie

c) stative verbs: sjediti 'to sit' $\rightarrow$ sjedenje; Slo. sedeti $\rightarrow$ sedenje; Pol. siedzieć $\rightarrow$ siedzenie

\subsection{Some conclusional preliminaries for Slavic Languages}

Firstly, we will present Table 1, which shows all productive deverbal nominalizations in Croatian and illustrates all the variability of formation rules:

\begin{tabular}{|l|l|l|}
\hline suffix & input & output \\
\hline -a & V pf, impf, tr, intr & $\mathrm{N}$ ev, res \\
\hline -ač & V impf, pf, tr, intr & $\mathrm{N} \mathrm{ag}$ \\
\hline -ada & V diasp & N sem act, res \\
\hline -aj & V pf, impf, tr, intr & N sem act, ev, res \\
\hline -ak & V pf, impf, tr, intr & N ev, res, inst \\
\hline -ar & $\begin{array}{l}\text { V pf, impf, tr, intr } \\
\text { N }\end{array}$ & $\mathrm{N} \mathrm{ag}$ \\
\hline -aš & $\mathrm{N}$ & $\mathrm{N} \mathrm{ag}$ \\
\hline -ba & V pf, impf, tr, intr & $\mathrm{N} \mathrm{ev,} \mathrm{res}$ \\
\hline
\end{tabular}

\footnotetext{
36 The nouns probijač and prebijač denote instrumental nouns.

${ }^{37}$ In Polish there is a verb wieczerzać but it is not used frequently.
} 


\begin{tabular}{|l|l|l|}
\hline -će & V pf, impf, tr, intr & $\mathrm{N}$ res, ev \\
\hline -nje & V pf, impf, tr, intr & $\mathrm{N}$ ev, res, obj \\
\hline -acija & V diasp & $\mathrm{N} \mathrm{ev}$, res \\
\hline -džija & V imp, intr $\mathrm{N}$ & $\mathrm{N} \mathrm{ag}$ \\
\hline -ik & V pf, impf, tr, intr & $\mathrm{N} \mathrm{ag}$ \\
\hline -ina & V perf, tr & $\mathrm{N}$ res \\
\hline -ka & V pf, impf, tr, intr & $\mathrm{N}$ res, obj, ev \\
\hline -nja & V pf, impf, tr, intr & $\mathrm{N}$ ev \\
\hline -lo & V impf, pf, tr, intr & $\mathrm{N}$ ag \\
\hline -telj & V pf, impf, tr, intr & $\mathrm{N}$ ag \\
\hline zero suffix & V impf, pf, tr, intr & $\mathrm{N} \mathrm{ev,} \mathrm{ob,} \mathrm{pl,} \mathrm{ag}$ \\
\hline
\end{tabular}

Table 1: All productive deverbal nominalizations in Croatian and all the variability of formation rules

It is difficult to define what an event/process and agentive noun is: this notion is widely based on verbal nouns as morphologically marked items. Many deverbal nouns are not purely eventive/process and agentive (instrumental, object). Some event and agentive nouns do not have a corresponding verb, are not derived from a verb, and they are not derivative at all (rat, zabava, mir). We have seen that the argument structure of an event noun cannot assure the well-balanced description of this notion.

Regarding Aspect, there are three levels (Pref, Suf, Root) of the realization of Aspect, and the difference in syntactic behaviour of aspectually marked nominals favours the separation of occurrences and processes on the morphological or lexical level from processes on the syntactic level. Deverbal nominals mainly do not carry aspectual markers.

Applying a test of the eventive reading of deverbal nouns to nominals with the most productive suffixes and the zero suffix, we found that nominals formed from imperfective/durative verbs have event interpretation (Ivanov hod danima 'John's walk for days'), but perfective/non-durative verbs may also have event interpretation (očev doček sina 'the father's welcoming of his son', dječakov vapaj noću. 'boy's cry at night', njegov vapaj traje još i sada 'his cry still lasts'). ${ }^{38}$

A particular problem is presented by the existence of complex morphological forms which are derived from verbal bases, but which do not preserve the argument structure of the source verb. This is the case for agentive and event/result nominals derived from transitive verbs, which appear to lose their internal argument or their whole argument structure. The evidence shows that there is no obligatoriness in the external argument nor in the structure of complex event/nominals.

Finally, it is possible to form agentive nominals from unaccusative verbs with suffixes (-ač, $n i k,-a r,-a c z,-e c$ etc.). Furthermore, the neutralisation of the morphological features of aspect indicates the absence of verbal functional categories in the structure of agentive nominals. Since adverbs are inseparably tied to the aspect head, they must be able to appear in structures with morphologically realized aspect, although there are nominals (e. g., -ač) which contradict this

\footnotetext{
${ }^{38}$ According to our interviews with native speakers, complements to nominals derived from perfective verbs also point to event interpretation.
} 
assumption. Therefore, there are no satisfactory mechanisms in DM theory for analysing languages of this morphological type.

\section{The analysis of deverbal nouns in Romance languages}

Since the event interpretations of nominals correlates with various syntactic properties, and since, in our view, the presence of the temporal-aspectual modifiers is more important for Slavic languages, the analysis of Romance languages will focus more on another important property: the obligatory realization of the arguments of the verbal base.

As we have already seen, the distinction between argument and non-argument nouns causes the distinct reading of eventive/process nouns (e. g., It. sanificazione dell'ambiente 'recovery of the environment', Fr. récupération de l'environnement, Sp. sanacion del ambiente). The noun examination (It. esaminazione, Fr. examen, Sp. examen, examinacion) also has an argument structure. According to the possibility of the use of aspectual modifiers, in English the noun examination is a complex event noun, and exam is a simple event noun: the examination of the documents in two hours, *the exam in two hours (cf. Alexiadou 2001: 11). But in Italian and in the other analysed languages, neither noun can be modified in this way; that is, they are not quite grammatical: It. 'l'esaminazione degli studenti in due ore, Cro. 'ispitivanje studenata u dva sata, Fr. 'test des élèves en deux heures.

According to Alexiadou and Grimshaw (2008) eventive nouns in English cannot take indefinite articles or the number one (*an/one examination), but in Slavic and Romance languages it is admitted: It. una sostituzione di un membro della commissione 'a substitution of a member of the commission', Fr. une enquête sur les vestiges archéologiques, Sp. basados en una examinacion de transcriptos.

English eventive nouns cannot take a predicate role (*this is an examination), but this is possible in other languages: It. questo è una sostituzione del presidente della commissione; Fr. c'est un remplacement d'un membre de la commission, Sp. esto es una substitucion de un membro de la comision, Cr. to je jedna zamjena.

Genitives that occur with eventive nouns are agents, while result nouns occur with possessives. In Italian and in other languages, the following is possible: la classificazione/classifica del professore degli studenti 'the professor's classification of students'.

Examples from both Slavic and Romance languages show that, contrary to what is predicated by Grimshaw's analysis, deverbal nominals can pluralize on their eventive reading.

Let us consider the following Italian examples with the word cambiamento, which denotes a complex event, and cambio, which denotes a simple event or result noun: $i$ grandi cambiamenti/*cambi della famiglia sono in atto da decenni 'big changes in the family have been taking place for decades'; l'episodio non comporterà alcun cambio di programma 'the episode will not cause any program change'; le monete delle varie economie si scambiano attraverso il mercato dei cambi (result noun) 'the currencies of various economies are exchanged through the foreign exchange market'; è arrivato il cambio(referential noun) 'the change has arrived'. 
But there are cases in which these nouns appear in the same linguistic contexts: fare il cambiamento/cambio della biancheria una volta la settimana; ci hanno costretto a un cambiamento/cambio di programma; un cambio/cambiamento di vita radicale.

These examples, as well as many others that we have illustrated, show that a consistent difference between simple and complex event deverbal nominals does not exist.

However, there is an important difference between the syntactic behaviour of deverbal nominals formed from the same verbal stem but with different suffixes. This can be illustrated by the deverbal nouns discesa and discendenza, both of which are derived from the verb discendere: Lo scalatore discese la montagna dopo aver toccato la vetta 'The climber descended from the mountain after reaching the top'/*La discendenza della montagna da parte dello scalatore; Mario discende da nobile stirpe 'Mario descends from a noble lineage'/*La discesa di Mario da nobile stirpe.

The verb discendere has transitive and intransitive meanings. When it is used in with its intransitve meaning, it can have: (a) one internal argument (sono disceso dal treno 'I descended from the train'), or (b) two internal arguments (dalla cima sono disceso velocemente a fondo valle 'from the top I descended quickly to the valley'). In the first case, the verb discendere has three semantic functions: uscire 'to exit', degradare (calare verso il basso) 'to degrade', and provenire (nascere, aver origine) 'originate'. The verb discendere/provenire can have an external argument with the property [ ${ }^{ \pm}$animate]: Luca discende da una famiglia nobile 'Luca originates from a noble family'/Le mie conclusioni discendono dalle premesse considerate 'My conclusions derive from the considered assumptions'. In both cases, the Aktionsart of the verb discendere is the same, but the construction *La discendenza delle mie conclusioni... is not correct. Consequently, the property of the verbal base [+stative] does not determine the selection of verbal base by the suffix. The verb accogliere and its derivatives accoglienza/accoglimento ('atto di accogliere') behave similarly: the suffix -enza selects the verb accogliere 'receive, accept' with an external argument characterised by the feature [+animate], whereas the suffix -mento selects the verb with external argument characterised by the feature [-animate] - e. g., accoglimento di una richiesta 'acceptance of a request'.

The pan-Romance deverbal suffixes (according to Tekavčić 1972: 85) are the following: It. -anza/-enza, Fr. -ance/-ence, Sp. -ancia/-encia, -anza; ${ }^{39}$ It. -mento, Fr. -ment, Sp. -miento/mento; It. -tore/-sore, Fr. -ur; Sp. -dor; It. -toi, Fr. -ior, Sp. -(d)ero; It. -tura/-sura, Fr. -ure, Sp. -(d)ura; It. -zione/-sione/-gione/, Fr. -aison/-tion, Sp. -zon/-ción/-sión.

The analyses below begin with Italian, and the examples in the other two langauages are mentioned in addition. For the Italian corpus we used the dictionary Sabatini/Coletti (2008), Corpus del quotidiano La Repubblica and Corpus dell'italiano scritto (CORIS). ${ }^{40}$ For French we used Grevisse/Goosse (2009) and Dubois (2002), and for Spanish we used Lang (1997), Alvar Ezquerra (1999), and Alcina Franch/Blecua (1983). ${ }^{41}$

\footnotetext{
39 This Spanish suffix -anza is a popular form.

$40 \mathrm{http}$ ://dev.sslmit.unibo.it/corpora/corpus.php?path=\&name=Repubblica [18.05.2016];

http://corpora.dslo.unibo.it/coris_ita.html [18.05.2016].

41 We also used El Corpus del Español del Siglo XXI (CORPES XXI) (http://www.rae.es/recursos/banco-de-datos/corpes-Xxi [18.05.2016]) and Corpus français (http://wortschatz.uni-leipzig.de/ws_fra [18.05.2016]).
} 


\subsection{The analysis of event nouns}

In the Italian language, event nouns are derived by suffixal formation or by conversion. Since a large subset of Italian deverbal nouns were already derived in Latin, and because sometimes it is not even possible to determine with certainty when the noun was first formed, the formation of nouns in this thesis is perceived as a continuation without sharp boundaries between these languages. Event nouns are therefore associated with Italian verbs as if they were derived from them, as they are, as a matter of fact, linked in the linguistic awareness of the speakers. Event nouns are divided according to their word-formation models: (a) suffixation, e. g., -zione (punizione $\leftarrow$ punire 'to punish'), -mento (collocamento $\leftarrow$ collocare 'to place'), ${ }^{42}$-tura (dettatura $\leftarrow$ dettare 'to dictate'), -aggio (montaggio $\leftarrow$ montare 'to assembre'), -anza/-enza (partenza $\leftarrow$ partire 'to depart'), -io (ronzio $\leftarrow$ ronzare 'to buzz'), $-\varnothing$ (rimborso $\leftarrow$ rimborsare 'to refund'), (b) converted past participle (female -ata/uta/ita, male -ato/-ito) (nuotata $\leftarrow$ nuotare 'to swim'; battuta $\leftarrow$ battere 'to beat'; udita $\leftarrow$ udire 'to hear') and (c) converted infinitive (il cantare $\leftarrow$ cantare 'to sing'). In addition to these, we also analysed event nouns that are not formed from verbs. These nouns are often derived from verbs in Latin, and usually those same verbs exist in Italian: e. g., Lat. stimulus ( $>$ It. stimolo) $\rightarrow$ Lat. stimulare (> It. stimolare 'to stimolate'); Lat. examen ( $>$ It. esame) $\rightarrow$ Lat. examinare ( $>$ It. examinare 'to examinate') ${ }^{43}$ There are also some nouns that do not have a verbal counterpart (e. g., strage). The same wordformation patterns also exist in French and Spanish. The most common event suffixes in French are: -ure, -ature, -ade, -aison,-ation, -ition, -erie, -ée, -(e)ement, -age, -ade.

The nouns are also analysed according to the number of arguments. Every argument has a thematic role and is important for the representation of the argument structure. Also included the analysis are the situation types (state, process and translation), as well as the lexical aspect of verbs and deverbal nouns by using the features of dynamicity, durativity, and telicity.

Considering that Slavic languages have morphologically expressed aspect, we have analysed those languages according to those categories. In Romance languages, aspect is expressed by the verbal tenses, but they have lexically expressed Aktionsart. In Slavic languages it is not possible for event nominals to be followed by two genitive arguments, which has been noted in certain Romance languages: la descrizione di Mario di Lucia 'the Mario's description of Lucia'.

In our analysis we will use the following thematic roles: Agent, Theme, Experiencer, Receiver, Location/Goal/Origin. ${ }^{44}$ The morphosyntactic realisations of the arguments can be the following: NP - nominal phrase, $\mathrm{PS}_{\mathrm{dpdi}}$ - prepositional phrase with da parte di, $\mathrm{ps}_{\mathrm{di}}$ - prepositional phrase with the preposition $d i, \mathrm{ps}_{\mathrm{a}}$ - prepositional phrase with the preposition $a, \mathrm{ps}_{\mathrm{da}}-$ prepositional phrase with the preposition $d a$, pa-possesive adjective, aa - argumental adjective.

\footnotetext{
42 The suffixes -zione and -mento are the most productive in the formation of event nouns.

${ }^{43}$ The same pattern is present in Gallicisms - i. e., Fr. analyse (> It. analisi) $\rightarrow$ analyser ( $>$ It. analizzare).

44 The segments of the analysed examples are underlined in the following way: a double line is used for the head (verb or noun), a single line for arguments, and a broken line for adjuncts. The arguments are marked by the abbreviations for thematic roles.
} 


\subsubsection{The suffix -zione}

The nouns formed by the suffix -zione can denote an action (without aspectual characteristics) or the result of that action. ${ }^{45}$ The following examples show this difference in meaning; in the first example there is a noun that denotes action, and in the second, the result:

(15) Ita. la costruzione di complessi edili da parte di imprese 'the construction of building complexes by companies'

la nuova costruzione è brutta

'the new construction is ugly'

The majority of Italian nouns that end in -zione should be considered inherited from Latin. Only neologisms present original deverbal formations in Italian, e. g., gassificare $\rightarrow$ gassificazione 'gasification'.

One example with the suffix -zione is alienazione 'alienation' (alienazione di un bene mobile a un estraneo), which drives from the verb alienare, which is durative and transitive. The Agent and Theme of the verb alienare are expressed by nominal phrases, and the third argument is expressed by a prepositional phrase with the preposition $a$ or $d a$ (depending on whether it is an Experiencer or a Location). The Agent of the noun alienazione is realized by a prepositional phrase with da parte di or by a possessive adjective. The Experiencer and Location are realized in the same way as with the verb.

(16) Ita. ha alienato a Damasco Exp il mondo arabo e l'Iran

'he has alienated from Damascus the Arab world and Iran'

le cose che ho sempre detto non $\underline{\text { mi}} \operatorname{Exp} \underline{\text { hanno mai alienato la simpatia dei }}$ $\underline{\text { tifositie }}$

'the things I've always said have never alienated the sympathy of the fans'

All the arguments can be realized with the noun; in addition, the noun, as well as the verb, can have adjuncts denoting place, time or manner. The noun can also be in plural form:

(17) Ita. alienazione di un bene mobile $\mathrm{Te}$ a un estraneo ${ }_{\text {Exp }}$ 'the alienation of movable property to a stranger'

l'alienazione dello spirito nello spazio

'the alienation of the spirit in space'

alienazione da sé stesso per il sacrificio

'alienation from himself for sacrifice'

l'alienazione in due settimane

'the alienation in two weeks'

\footnotetext{
45 The origin of this suffix is connected to the suffix -io that used to be added to the past participle and that in the accusative has the form -ione $(m)$. In the Romance languages, the final consonant is usually dropped, because the Italian form is -zione (cf. Tekavčić 1972: 84-85). If we take the Latin verb punire as an example, the process is as follows: punit- + -ione $(m) \rightarrow$ punitione $(m)>$ It. punizione.
} 


alienare
\begin{tabular}{|l|l|l|l|}
\hline Ag & Te & Exp & Loc \\
\hline $\mathrm{NP}_{-}$ & $\mathrm{NP}$ & $\mathrm{PP}_{\mathrm{a}}$ & $\mathrm{PP}_{\mathrm{da}}$ \\
\end{tabular}

alienazione
\begin{tabular}{|l|l|l|l|}
\hline $\mathrm{Ag}$ & $\mathrm{Te}$ & Exp & Loc \\
\hline $\begin{array}{l}\mathrm{PP}_{\text {dpdi }} \\
\text { pa }\end{array}$ & $\mathrm{PP}_{\mathrm{di}}$ & $\mathrm{PP}_{\mathrm{a}}$ & $\mathrm{PP}_{\mathrm{da}}$ \\
\hline
\end{tabular}

This nominal can be also used in plural form:

(18) Ita. luogo delle proiezioni, desideri e alienazioni dell'io reale 'place of projections, desires and alienations of the real ego'

In Spanish there is also the noun derived from alienar. The following examples show this noun in singular and in plural:

(19) Ita. le da un sentido de la alienación del objeto

'it gives a sense of alienation from the object'

los intercambios y las alienaciones de inmuebles necesarios

'exchanges and alienations of indispensable real estate'

Here are some examples for the French word aliénation in singular and in plural:

(20) Fra. aliénation des travailleurs de leur propre entreprise

'workers' alienation from their own company'

aliénation de l'homme de l'homme

'alienation of man from man'

les aliénations de biens et droits indivis

'the alienations of property and rights'

The same suffix appears in the Italian word apparizione 'appearance, apparition', derived from the verb apparire which is durative, intransitive and unaccusative. It may also take the plural form:

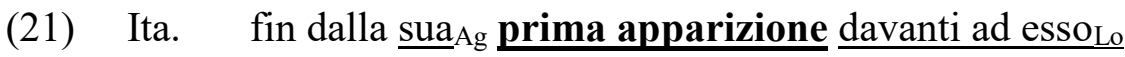

'from her first appearance in front of him'

le visioni o le apparizioni della Vergine Santa $\mathrm{Ag}$

'visions and appearances of the Holy Virgin'

apparire

\begin{tabular}{|l|l|}
\hline Ag & Lo \\
\hline NP_ & PP \\
NP & \\
\hline
\end{tabular}

apparizione

\begin{tabular}{|l|l|}
\hline $\mathrm{Ag}$ & Lo \\
\hline $\begin{array}{l}\mathrm{PP}_{\mathrm{di}} \\
\mathrm{pa}\end{array}$ & $\mathrm{PP}$ \\
\hline
\end{tabular}

This noun can also denote a result:

(22) Ita. era pallida come se avesse visto un'apparizione 'she was pale as if he had seen an apparition'

The French noun apparition, which can also have the two above-mentioned meanings:

(23) Fra. l'apparition de l'homme sur la Terre

'the appearance of man on the Earth'

l'apparition s'évanouit dès qu'on s'en approcha 
'the apparition vanished as soon as we approached it'

The Spanish noun aparición has the same characteristics:

(24) Spa. en su artículo da noticia de la aparición de un nuevo incunable

'in his article [he] gives a notice about the appearance of a new incunable'

asegura haber visto una aparición en el castillo abandonado

'he claims to have seen an apparition in the abandoned castle'

The noun costruzione has a two-argument structure like the verb costruire (which is transitive, durative, dynamic and telic):

(25) Ita. Arnault $\mathrm{Ag}$ ha costruito in pochi anni un impero invidiabile ${ }_{T h}$

'Arnault has built an enviable empire in a few years'

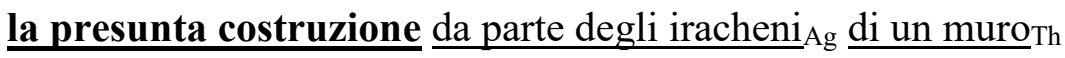

'the presumed construction by the Iraqis of a wall'

qualche anno dopo le costruzioni furono bloccate

'a few years later the construction was blocked'

Verb arguments are expressed by nominal phrases. The Agent of the noun costruzione can be a prepositional phrase with the expression da parte di, a possessive adjective or argument adjective. The Theme of the noun is expressed by a prepositional phrase with $d i$ or by a possessive adjective:

\begin{tabular}{l} 
costruire \\
\begin{tabular}{|l|l|}
\hline $\mathrm{Ag}$ & $\mathrm{Te}$ \\
\hline $\mathrm{NP}_{-}$ & _ NP \\
\hline
\end{tabular} \\
\hline
\end{tabular}

costruzione

\begin{tabular}{|l|l|}
\hline $\mathrm{Ag}$ & $\mathrm{Te}$ \\
\hline $\mathrm{PP}_{\text {dpdi }}$ & $\mathrm{PP}_{\mathrm{di}}$ \\
pa & $\mathrm{pa}$ \\
$\mathrm{aa}$ & \\
\hline
\end{tabular}

The Spanish noun construcción can also denote action (fuimos a ver cómo iba la construcción de nuestra casa 'we went to see how was going the building our house'), the result (una construcción moderna 'a modern construction') or 'building industry' (trabajo en la construcción 'I work in the construction industry').

\subsubsection{Suffix -mento}

This suffix originates from the Latin suffix -mentum (cf. Tekavčić 1972: 71-72). It forms abstract nouns which denote action/event (posizionamento 'positioning', straniamento 'estrangement'), consequence (inquinamento 'pollution'), result (armamento 'arming') or state (isolamento 'isolation'). Nouns with this suffix can also have a concrete meaning: monumento 'monument', medicamento 'medicine', ornamento 'ornament'. The suffix -mento mostly does not introduce into the noun changes in terms of aspect and Aktionsart, but rather the resulting nouns inherit those characteristics from the original verbs. 
There are some differences between the nouns formed by the suffix -mento and those formed in other ways: cambiare 'to change' $\rightarrow$ cambiamento i cambio; collocare 'to place' $\rightarrow$ collocamento i collocazione (cf. Dardano 2009: 71).

The noun allevamento 'breeding, rearing, raising, bringing up' is formed from the verb allevare, which is transitive, durative, and dynamic. As a result, this noun can mean the totality of animals or plants being raised somewhere or the place where the action takes place. The verb has two arguments, and the noun can also have two arguments:

(26) Ita. Dionisio Minaggio Ag allevava uccelli ${ }_{\mathrm{Th}}$

'Dionisio Minaggio was breeding birds'

$\underline{\text { l'allevamento del bambinoth }} \underline{\text { da parte di adulti che dispongano di adeguat }}$ personalità $\mathrm{Ag}$

'the raising of the child by adults who have adequate personality'

allevare
\begin{tabular}{|l|l|}
\hline Ag & Th \\
\hline $\mathrm{NP}_{-}$ & NP \\
\hline
\end{tabular}

allevamento

\begin{tabular}{|l|l|}
\hline $\mathrm{Ag}$ & $\mathrm{Th}$ \\
\hline $\mathrm{PP}_{\mathrm{dpdi}}$ & $\mathrm{PP}_{\mathrm{di}}$ \\
\hline
\end{tabular}

There is a similar noun in French, élevage, derived from the verb élever (traité d'apiculture ou de l'élevage des abeilles 'treaty on apiculture or the keeping of bees'). The Spanish noun cria refers to the action (se dedicaba a la cría de caballos 'he was dedicated to horse breeding'), while the place is criadero (nos llevó a visitar su criadero de canarios 'he took us to visit his farm of canaries').

\subsubsection{Suffix -aggio}

Nouns with -aggio normally describe a durative, continuous action and can be paraphrased using the expression operazione di: filtraggio "operazione del filtrare", rimontaggio "operazione del rimontare". ${ }^{46}$ A subset of Italian nouns with -aggio is taken from French, in which they are formed with the suffix -age): lavaggio $<$ fr. lavage $\leftarrow$ laver 'to wash', montaggio $<\mathrm{fr}$. montage $\leftarrow$ monter 'to assemble' (cf. Tekavčić 1972: 59).

The noun filtraggio is connected with the verb filtrare ${ }^{47}$ which is $[ \pm$ transitive], [+durative], [+dynamic]. The intransitive verb (with the arguments Agent and Origin) means 'to percolate, to seep' and the transitive verb (with the arguments Agent and Theme) means 'to filter, to strain':

(27) Ita. gocce d'acqua $A$ filtrano dal cavernoso soffitto

'drops of water seep from the cavernous ceiling'

$\underline{\text { entrambi }}$ Ag hanno filtrato $\underline{\text { le domande dei giornalisti }}$ Te

'they both have filtered the questions of journalists'

\footnotetext{
46 The suffix -aggio entered Italian from medieval French, in which the form -age originates from the Latin suffix -atǐcus (Tekavčić 1972: 58-59).

47 This verb is taken from French, where the verb filtrer is derived from the noun filtre.
} 
The meaning of filtraggio corresponds to the transitive verb and has Agent and Theme:

(28) Ita. filtraggio delle acque $\underline{T e}_{\text {da parte di queste specie viventi }}{ }_{\mathrm{Ag}}$ 'water filtration by these living species'

filtrare $_{1}$
\begin{tabular}{|l|l|}
\hline $\mathrm{Ag}$ & $\mathrm{Th}$ \\
\hline $\mathrm{NP}_{-}$ & $\mathrm{NP}$ \\
& \\
\hline
\end{tabular}

filtrare 2
\begin{tabular}{|l|l|}
\hline Ag & Or/Go \\
\hline NP_ & PP \\
& \\
\hline
\end{tabular}

filtraggio
\begin{tabular}{|l|l|}
\hline $\mathrm{Ag}$ & $\mathrm{Th}$ \\
\hline $\mathrm{PP}_{\mathrm{dpdi}}$ & $\mathrm{PP}_{\mathrm{di}}$ \\
$\mathrm{pa}$ & $\mathrm{pa}$ \\
$\mathrm{aa}$ & \\
\hline
\end{tabular}

The action of the intransitive meaning of the verb can be expressed by the noun filtrazione (and infiltrazione):

(29) Ita. sono state avvertite pericolose filtrazioni di gas attraverso le fessure delle pareti

'a dangerous leakage of gas through the cracks of the walls was noticed'

French also has both nouns, filtrage and filtration, as does Spanish, filtraje and filtración: el depósito se vació por la filtración de la gasolina a través de una grieta 'the tank was emptied by letting the gasoline leak through a crack'.

\subsubsection{Suffix -tura}

The meanings of nouns with the suffix -tura are mostly abstract and eventive, but often can be concretized: ${ }^{48}$ scrittura can mean 'writing' and also 'something written', cucitura can be 'sewing' and 'seam'. ${ }^{49}$ Some nouns with this suffix have their pairs formed by another suffix: mento (rigonfiatura/rigonfiamento 'reinflating') ${ }^{50}$, or by zero suffix (ratificatura/ratifica 'ratification').

The above-mentioned noun cucitura derives from cucire. This verb is durative and dynamic and can be transitive or intransitive. The intransitive variant is unergative, and its meaning is connected to the practise of that profession: uno cuce, l'altro strappa 'one sews, the other snatches'. As a transitive verb, it has Agent and Theme:

(30) Ita. venti bambini $A g$ hanno cucito vestiti Te per le bambole di carta 'twenty children have sewed clothes for paper dolls'

The noun cucitura has the same structure as a nominal phrase with the verb cucire:

\section{Ita. la cucitura di palloni ${ }_{\mathrm{Te}}$ da parte dei bambini ${ }_{\mathrm{Ag}}$} 'the sewing of balls by the children'

\footnotetext{
48 The suffix -tura derives from the terminal part of the nouns formed by the suffix -ura added to the participle base in Latin: dictare - dictat|um $\rightarrow$ dictatura, scribere - script|um $\rightarrow$ scriptura (Tekavčić 1972: 82-83).

${ }^{49}$ Some nouns ending in -tura have only concrete meaning (calzatura 'footwear', alberatura 'planting of trees, masting').

${ }^{50}$ Usually those with -tura were formed relatively recently. According to data from the dictionary Sabatini/Coletti: rigonfiamento ( $17^{\text {th }}$ cent.), rigonfiatura (1987).
} 

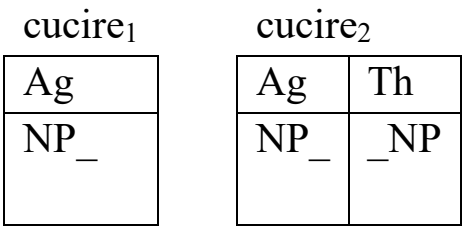

cucitura
\begin{tabular}{|l|l|}
\hline $\mathrm{Ag}$ & $\mathrm{Th}$ \\
\hline $\mathrm{PP}_{\text {dpdi }}$ & $\begin{array}{l}\mathrm{PP}_{\mathrm{di}} \\
\mathrm{pa}\end{array}$ \\
\hline
\end{tabular}

In this case, the Spanish and French nouns have suffixes of the same origin: Sp. costura (action and result of coser), Fr. couture (action and result of coudre).

\subsubsection{The suffix -anza/-enza}

The meaning of the event nouns with this suffix could be explained by a paraphrase with the expression atto di + verb: avvertenza - atto di avvertire, ordinanza - atto di ordinare. ${ }^{51}$

The formation basis for this suffix can be nouns and adjectives: cittadino $\rightarrow$ cittadinanza, gemello $\rightarrow$ gemellanza, sorella $\rightarrow$ sorellanza; lontano $\rightarrow$ lontananza, uguale $\rightarrow$ uguaglianza, (Dardano 2009: 73).

The noun avvertenza 'warning' is derived from the verb avvertire, which is transitive, nondurative and dynamic. It can have two or three arguments, and the third argument is Receiver. In the mono-argument variant, it means 'to notice, to feel', while the two-argument variant means 'to warn, to inform, to notify'.

(32) Ita. avverte veramente una fitta dolorosissimate

'feels really a very painful pang'

$\underline{\text { il Foreign Office }}_{A g}$ avverte $\mathrm{i}$ turisti inglesipr $\underline{\text { di stare attenti }}_{\mathrm{T}}$

'the Foreign Office warns British tourists to be careful'

The noun has the meaning of a three-argument word, but usually only one or two arguments are realized.

(33) Ita. con $\underline{\text { la }} \underline{\underline{\text { sua }}} \mathrm{Ag}$ avvertenza di superamento delle opposizioni nette $\mathrm{Te}$

'with his warning of overcoming the clear oppositions'

$\underline{\text { la }}$ loro $A g$ avvertenza ai teletifosiRe

'their warning to TV fans'

avvertire $_{1}$

\begin{tabular}{|l|l|}
\hline Ag & Th \\
\hline NP__ & NP \\
\hline
\end{tabular}

avvertire $_{2}$

\begin{tabular}{|l|l|l|}
\hline $\mathrm{Ag}$ & $\mathrm{Re}$ & $\mathrm{Th}$ \\
\hline $\mathrm{NP}$ & $\mathrm{NP}_{-}$ & $\mathrm{PP}_{\mathrm{di}}$ \\
\hline
\end{tabular}

avvertenza

\begin{tabular}{|l|l|l|}
\hline $\mathrm{Ag}$ & $\mathrm{Re}$ & $\mathrm{Th}$ \\
\hline $\begin{array}{l}\mathrm{PP}_{\text {dpdi }} \\
\text { pa }\end{array}$ & $-\mathrm{NP}$ & $\mathrm{PP}_{\text {di }}$ \\
\hline
\end{tabular}

Avvertenza can also be a result noun. In Spanish has the noun advertencia, which also denotes action and result. The corresponding French noun is avertissement.

\footnotetext{
51 The origin of this suffix is connected to the Latin suffix $-i a$, which in Latin used to be added to the present participle base: credere $\rightarrow$ credent- $+-i a \rightarrow$ credentia. Later, the final part of the base came to be interpreted as the initial part of the suffix, and today in Italian we talk about the suffix -anza/-enza.
} 
The noun partenza derives from the verb partire, ${ }^{52}$ which can be transitive and intransitive and can have from one to three arguments (Agent, Origin, Goal). In the mono-argument structure, it usually refers to an engine, with the meaning of 'to start', and there is also a corresponding noun:

(34) Ita. la chiave gira e la macchina $A \underline{\text { non parte }}$

'the key turns and the car doesn't start'

dopo la partenza del motore $\underline{A g}$

'after the start of the engine'

When there are other arguments the meaning is 'to leave, to depart, to set off, to set out':

(35) Ita. prima della sua $\mathrm{Ag}$ partenza da Romaor

'before his departure from Rome'

la partenza del presidente libanese Gemayel ${ }_{\mathrm{Ag}}$ per la Germania ${ }_{\mathrm{Go}}$

'the departure of Lebanese President Gemayel to Germany'

The noun inherits the meaning of the two/three-argument verb, i. e., it means 'departure, leaving':

(36) Ita. partenza dei ciclisti 'the departure of the cyclists for the tour of Sardinia'

sono state cancellate molte partenze da Milanoor per il sud ${ }_{\mathrm{Go}}$

'many departures from Milan to the south were canceled'

In Spanish there are two nouns, partida (action) and salida (action and place): la salida del tren será a las seis 'the departure of the train will be at six'. French has the form départ: retarder le départ de quelques minutes 'to delay the departure for a few minutes'.

\subsubsection{Suffix -io}

This suffix has always the same value: continuous action/event with stronger intensity (there is a difference between lavoro 'work' i lavorio 'intense work'). ${ }^{53}$ Nouns with this suffix mostly describe some kind of sound: (borbottare 'to grumble' $\rightarrow$ borbotio 'long grumbling'; cigolare 'to creak' $\rightarrow$ cigolio 'long creaking'), but there are also some with other meanings, like the aforementioned lavorio and also formicolio 'swarm, swarming, teeming' ( $\leftarrow$ formicolare).

The noun ronzio 'buzz' is derived from the verb ronzare, which is durative, intransitive and unergative:

(37) Ita. le api

'the bees are buzzing in the hive'

\footnotetext{
52 This verb has perfective Aktionsart; its imperfective counterpart is viaggiare.

53 The suffix -io derives from the ending -erium of Latin words which in front of the suffix -ium have the syllable -er- (e. g. desiderium, ministerium, imperium). Later the segment -erium began to be considered a suffix. As a result of phonological changes the suffix -erium become -io. However, besides this outcome, Latin nouns ending in -erium can also have other forms of the final segment in Italian: -ero (battistero, impero) i -erio (desiderio, improperio). (Tekavčić 1972: 69).
} 
il ronzio concorde delle api ${ }_{\text {Ag }}$ nell'alveare

'the unanimous buzzing of the bees in the hive'

$\underline{\text { la partita }} \mathrm{Ag}$ ronza nelle teste e nelle gambe dei giocatori ${ }_{\mathrm{LO}}$

'the game is buzzing in the heads and legs of the players'

tutto questo ronzio attorno a tale temaLo

'all the buzz around this topic'

The verb ronzare in its basic meaning has only one argument, and the noun ronzio inherits that structure. The verb argument is expressed by an NP, and the noun argument by a PP with the preposition $d i$, while the location is an adjunct. When the 'buzz' is more abstract (psychic), it seems that the Location (expressed by a PP mostly with in) is also obligatory and is an argument:

\begin{tabular}{|l|}
\hline ronzare \\
\hline $\mathrm{Ag}$ \\
\hline $\mathrm{NP}_{-}$ \\
\hline
\end{tabular}

ronzare 2
\begin{tabular}{|l|l|}
\hline $\mathrm{Ag}$ & $\mathrm{Lo}$ \\
\hline $\mathrm{NP}$ & $\mathrm{PP}$ \\
\hline
\end{tabular}

\begin{tabular}{|l|}
\multicolumn{1}{l}{ ronzio $_{1}$} \\
\hline $\mathrm{Ag}$ \\
\hline $\mathrm{PP}_{\mathrm{di}}$ \\
\hline
\end{tabular}

ronzio 2
\begin{tabular}{|l|l|}
\hline $\mathrm{Ag}$ & $\mathrm{Lo}$ \\
\hline $\mathrm{PP}_{\mathrm{di}}$ & $\mathrm{PP}$ \\
\hline
\end{tabular}

The equivalent French nouns are formed by a different suffix: bourdonnement, vrombissement, ronflement. The Spanish noun is zumbido, e. g. el zumbido de las abejas 'the buzzing of the bees', un zumbido en la cabeza 'a buzz in the head'.

Another noun with this suffix is calpestio 'trampling' (Sp. pisoteo, Fr. piétinement). It is derived from the verb calpestare 'to step on', which has two arguments and is [+ transitive], [+ durative], [+ dinamic].

(38) Ita. arriva l'extracomunitario ${ }_{A g}$ e calpesta l'erbetta del tuo giardino $\mathrm{Te}$

'the immigrant comes and tramples the grass in your garden'

The noun calpestio does not keep the argument structure of the verb, and it has only one argument. It also has a different meaning from the continuous walking and the sound that is produced by walking. There is also another noun, calpestamento, formed with a different suffix, which keeps the argument structure and the meaning of the verb.

(39) Ita. quando avvertimmo un calpestio di cavalli

'when we noticed the trampling of horses behind us'

$\underline{\text { il calpestamento }}$ di un tetto di eternit $\mathrm{Te}$ da parte di un muratore ${ }_{\mathrm{Ag}}$ 'the trampling of a roof of asbestos by a mason'

\begin{tabular}{l} 
calpestare \\
\begin{tabular}{|l|l|}
\hline $\mathrm{Ag}$ & $\mathrm{Te}$ \\
\hline $\mathrm{NP}$ & NP \\
\hline
\end{tabular} \\
\hline
\end{tabular}

\begin{tabular}{|l|} 
calpestio \\
\hline $\mathrm{Ag}$ \\
\hline $\mathrm{PP}_{\mathrm{di}}$ \\
$\mathrm{pa}$ \\
\hline
\end{tabular}

calpestamento
\begin{tabular}{|l|l|}
\hline $\mathrm{Ag}$ & $\mathrm{Te}$ \\
\hline $\mathrm{PP}_{\text {dpdi }}$ & $\mathrm{PP}_{\mathrm{di}}$ \\
pa & pa \\
\hline
\end{tabular}

\subsubsection{The suffix - ata}

The event nominals with -ata are normally semelfactive. This suffix originates from the Latin past participle. 
The Italian noun passeggiata 'walk' is derived from the verb passeggiare which is [+durative] and $[ \pm$ tranisitve]. It can have only one argument or can also have a Theme.

(40) Ita. da quelle parti passeggia il capitano Ag ogni giorno

'over there the captain walks every day'

abbiamo passeggiato il cane $T$ tutta la mattina

'we walked the dog all morning'

la passeggiata di Mitterrand ${ }_{\mathrm{Ag}}$ in Montenapoleone

'Mitterrand's walk in Montenapoleone'

la passeggiata del cane ${ }_{T e}$ finisce qui

'the walking of the dog ends here'

\begin{tabular}{|l|} 
passeggiare $_{1}$ \\
\hline $\mathrm{Ag}$ \\
\hline $\mathrm{NP}$ \\
\hline
\end{tabular}

passeggiare 2
\begin{tabular}{|l|l|}
\hline $\mathrm{Ag}$ & $\mathrm{Th}$ \\
\hline $\mathrm{NP}$ & $\mathrm{NP}$ \\
& \\
\hline
\end{tabular}

\begin{tabular}{|l|} 
passeggiata $_{1}$ \\
\hline $\mathrm{Ag}$ \\
\hline $\mathrm{PP}_{\mathrm{di}}$ \\
$\mathrm{PP}_{\mathrm{dpdi}}$ \\
\hline
\end{tabular}

passeggiata 2
\begin{tabular}{|l|l|}
\hline $\mathrm{Ag}$ & $\mathrm{Th}$ \\
\hline $\mathrm{PP}_{\mathrm{di}}$ & $\mathrm{PP}_{\mathrm{di}}$ \\
& \\
\hline
\end{tabular}

In Spanish the noun paseo is formed differently, but it has the same meanings of action and place (daremos un paseo por la playa 'we will walk along the beach'). The same applies to the French noun promenade (le mauvais temps m'empêchant de sortir pour la promenade 'the bad weather prevented me from going out for a walk').

\subsubsection{The zero suffix}

The zero suffix formation is a kind of word formation in which a phonetically empty element is added to the lexical base (cf. Scalise/Bisetto 2008: 198). Along with a noun formed in this way, there is usually another noun formed by suffixation from the same verb, e. g. delibera deliberazione, rivendica - rivendicazione. In such cases, the difference often concerns the meaning (e. g., verifica has four meanings and verificazione has two; gratifica and gratificazione have four completely different meanings each); nouns with -zione generally emphasize more the durativity, while the nouns with zero suffix often refer to the result.

The noun verifica means 'control, check' (verifica dei passaporti 'passport control') or 'examination, inspection' (la verifica dei nuovi macchinari 'the inspection of the new machines'). This corresponds to the meanings of the verb verificare. The noun verificazione is used only in specific contexts, such as in legal language (la verificazione di un atto notarile 'the verification of a notarial act') and in philosophy (principio di verificazione 'verifiability principle'). Such words with zero suffix do not exist in French and Spanish, but there often is a suffixed one (vérification, verificación) paired with another of equivalent meaning (contrôle, control).

In Italian, like in the other Romance languages analysed here, the majority of event nominals may also take plural forms even when they have event and telic meaning. Besides the already mentioned examples, here are some others: fluttuazioni, esaltazioni, restituzioni, sparizioni, spostamenti, fioriture.

(41) Ita. fluttuazioni dei mercati valutari

'fluctuations in currency markets' 
Spa. fluctuaciones de la economía española

'fluctuations in the Spanish economy'

Fra. fluctuations incontrôlées des prix du pétrole 'wild swings in oil prices'

Ita. queste esaltazioni dei miti borghesi

'these exaltations of bourgeois myths'

sparizioni di persone per mano di agenti segreti

'disappearances by the hands of secret agents'

gli spostamenti sono continui

'the displacements are continuous'

fioriture spontanee dello spirito popolare

'spontaneous blooms of popular spirit'

\subsection{Event nouns not derived from verbs}

There are also some event nouns that are not derived from verbs in Latin or in some Romance language, but in their etymologia remota are normally of deverbal origin. These nouns have the meaning of an action/event and behave like other event nouns. From these nouns verbs are usually formed.

In some cases, the noun was passed down from Latin, and a verb that in Latin had been formed from that noun was also passed down to Italian:

Lat. stīmulus 'goad' $\rightarrow \quad$ Lat. stimulāre 'to prick with a goad'

Ita. stimolo

Ita. stimolare

The noun stimolo does not have the concrete meaning of a sharp object but only an abstract one (eventive) ${ }^{54}$ e. g., aspettano lo stimolo di una nuova catastrofe politica 'they expect the stimulus of a new political catastrophe'. From the derived verb is formed the noun stimolazione (< Lat. stimulatiōnem $\leftarrow$ stimulāre), which means 'incitement, stimulation', e. g. stimolazione del muscolo cardiaco 'stimulation of the cardiac muscle'. The same nouns exist in Spanish: estímulo, estimulacion. The corresponding French forms are stimulus and stimulation.

The origin of the It. noun guerra 'war' (Sp. guerra, Fr. guerre), which replaced the Classical Latin noun bellum, is Germanic (from the Franconian *werra). ${ }^{55}$ This noun is the base from which the verb is derived: It. guerreggiare, Sp. guerrear, Fr. guerroyer. The example guerra di popolo contro il terrorismo 'the war of the people against terrorism' can be tranformed into il popolo guerreggia contro il terrorismo 'the people make war against terrorism'.

\footnotetext{
${ }^{54}$ In this case it could seem that the noun is derived from verb.

55 The Classical Latin word is preserved in some words: bellico, belligerante.
} 
Some nouns do not have a verbal counterpart of same derivational base, but they are formed from a verb in Latin, such as the noun strage 'massacre', which countinues the Latin noun strāgem, derived from verb stěrnere. Agent and Theme are expressed as usual: la strage dei pini da parte di Roma Metropolitane 'the massacre of the pine trees by Roma Metropolitane'. The equivalent noun in Fr. is massacre, an in Sp. masacre and matanza.

All these results bring us to the conclusion that deverbal nouns denoting events govern the arguments in the nominal phrase in the same way as the verbs govern the arguments in the sentence, but there are differences in the morphosyntactic realization of the arguments. Some arguments of deverbal nouns are mostly expressed by a prepositional phrase. Our analysis also confirms that the realization of the noun arguments is more a possibility than a requirement, and they are not obligatory as are the verb arguments. It can also be concluded that the lexical aspect of a verb is not always identical with the lexical aspect of a noun derived from that verb, but often depends on the type of noun, which means also the type of suffix.

It is important to say that these types of nouns for the most part can be used without any arguments (which are implied). The argument of an unergative verb is an Agent and the argument of an unaccusative verb is a Thema. As regards the lexical aspect, it often depends on the type of noun, i. e. on the type of suffix - e. g., the suffix -aggio almost always denotes a durative action (filtraggio), and nouns with the zero suffix (arrivo) and those formed from past participles (succhiata) usually denote semelfactive (instantaneous) acts.

\section{$5 \quad$ Agentive nominals in Romance languages}

The formation of agentive nouns ${ }^{56}$ in Romance languages is similar as in Slavic languages in terms of the type of verb stems and morphosyntactic behaviour. The time and manner of adverbial expressions cannot be used with agentive nominals:

(42) Ita. *Luca è un autista abituale;

Fra. *Lucà et chauffeur habituele

'Luca is a habitual driver'

Ita. ha guidato il tir per tre ore;

Fra. ill condusait camion pendant trois heurs

'he drove the truck for three hours'

Ita. *guidatore di tir per tre ore;

Fra. * chaffeur de camion pendant trois heures

'driver of a truck for three hours'

The behaviour of the nominalizations of an agent can be seen in the following Italian examples:

(43) Ita. ho visto Gianni uccidere Mario

'I saw Gianni killing Mario'

\footnotetext{
56 This term is used in a broad sense to denote a person who is related to the action expressed by a verb (i. e., not only the causer of the action).
} 
*Ho visto l'uccisore di Mario da parte di Gianni. ${ }^{57}$

ha dato il lavoro agli operai

'he gave the work to the workers'

*il datore di lavoro agli operai

Mario ha affittato una casa a Gianni

'Mario has rented a house to Gianni'

* Gianni è l'affittuario della casa da parte di Mario.

Mario mi ha donato un libro

'Mario gave me a book'

*il dono di Mario di un libro a me

The examples show that these nominalizations do not permit the coexistence of the NP on which they are based. It is also impossible in French and Spanish.

The nominalizations of the agent contain the semantic property [+animate] and the paraphrase is "chi/la persona/colui che V" (a person who V): bidonatore "chi bidona" "who swindles"; rifondatore "chi rifonda" "who reestablishes'; rivestitore "chi riveste" "who coats'; sanzionatore "chi sanziona" "who sanctions'; rianimatore "chi rianima" "who reanimates'; convertista "chi converte" "who converts'. 58

The nominalization of instrumental nouns presents the semanic property [-animate] with the paraphrase "qualcosa/una cosa/la cosa che serve a V" ('something that is used for V'): frullatore "qualcosa/una cosa/la cosa che serve a frullare"; lavatrice "qualcosa/una cosa/la cosa che serve a lavare".

\subsection{Agentive nominals formed from unnacusative verbs}

According to the widely accepted opinion that unaccusative verbs cannot serve as a base for the formation of agentive nouns, following the list of unaccusative verbs in Italian (Salvi 1988: 4849), we have investigated the possibility of agentive nominal formation from those verbs.

The Italian verb affondare 'to sink, to send to the bottom' can be transitive and intransitive. The agentive nominal affondatore 'a person who orders or executes sinking' is formed from the transitive meaning. The equivalents of this word in Spanish are hudnidor and fundidor, derived from the verbs hundir and fundir. ${ }^{59}$ In French there are also two equivalent verbs: sombrer and couler.

\footnotetext{
${ }^{57}$ Uccisore is 'killer'. The same behaviour is in French: je vue Ivan assassinèe Lucà/*j'ai vu assassineur de Lucà par Ivan.

58 The meanings of these verbs are: bidonare 'to cheat, to trick, to swindle', rifondare 'to refound, to re-establish', rivestire 'to cover, to coat', sanzionare 'to sanction', rianimare 'to rianimate', fare sondaggi 'make enquiries', and convertire 'to convert'.

59 The dictionary of Algherese has the word fondador: Aqueix temps pot ésser l'afondador de tantes barques (http://www.algueres.net/vocabols/748/afondador_a.aspx [18.05.2016]). It corresponds to the Catalan word enfonsador.
} 
But the Italian nouns laureato 'graduate' and laureando 'who is going to graduate' are formed from the intransitive unaccusative verb laurearsi 'to graduate'. ${ }^{60}$ The French and Spanish forms lauréat and laureado, meaning 'prizewinner, laureate', are connected with transitive versions of corresponding verbs. In Spanish there is also the noun laureando as in Italian.

But the Italian nouns laureato 'graduate' and laureando 'who is going to graduate' are formed from intransitive unaccusative verb laurearsi 'to graduate'. The French and Spanish forms lauréat and laureado meaning 'prizewinner, laureate' are connected with transitive versions of corresponding verbs. In Spanish there is also the noun laureando as in Italian.

The Italian verb morire 'to die' has different agentive nominals, or, more precisely, the nouns for person semantically correlated with the action expressed by the verbal base: morto 'dead person', morituro, morente, moribondo 'dying person'. There are similar forms in French (mort, mourant, moribond) and in Spanish (muerto, moribundo). The verb morire can be used as a transitive predicate (hai morta l'innocente figlia 'you have killed the innocent daughter'), but in this sense the verb morire cannot be nominalized. Slavic languages also have this type of noun: umirući, mrtvac, mrtvi.

In Italian, the agentive nominal aumentatore is derived from aumentare - e. g., era alieno dalle rapine pubbliche e del bene comune aumentatore 'he was alien to public robberies and an enhancer of the common good'. The same noun exists in Spanish: aumentador ( $\leftarrow$ aumentar). In Fr. there are two nouns: augmentateur and augmenteur ( $\leftarrow$ augmenter). There is no noun with this agentive meaning in the Slavic languages.

In Italian, the verb avanzare can be used in the tranitive sense (avanzare una richiesta 'to push forward a request'), but it is interesting that there is no the agentive noun *avanzatore ( avanzatore delle richieste). However, there is an instrumental noun: avanzatore mandibolare 'mandibular advancer'.

Similary, the verb esplodere 'to explode' has an unnacusative meaning, and the noun esploditore has only the instrumental meaning of 'mine exploder'.

There is no agentive noun of the verb crescere 'to grow', but there is the noun adulto 'adult', which is a past participle (Lat. adultum $\leftarrow$ adolescere); Fr. adulte, Sp. adulto. In Croatian, the noun denoting an adult person is formed from the unaccusative verb odrasti and is a form of the so-called active participle: odrasli (the same as Pol. dorośli and Slo. odrasli).

The It. verb nascere forms different nominals: nascituro 'baby which will be born soon', nascente (in It. this does not does not refer to a human being, but only objects, e. g. proggetto nascente), il nato - patient noun (i nati tra le due guerre 'those born between the wars').

From the verb arrivare a patient noun can be formed: arrivato 'a person who come' and 'successful person, parvenu, upstart'. Another noun is formed differentially: arrivista (syn. arrampicatore) 'social climber, careerist, arriviste', Fr. arriviste, Sp. arribista.

Besides its literal meaning, the Italian noun entrante 'person who enters' ( $\leftarrow$ entrare) can also mean 'new, newly-appointed'. The French noun entrant means 'person who enters' but also

\footnotetext{
${ }^{60}$ Auxiliary selections and ne-cliticization (se ne sono laureati molti) are used as diagnoses for unaccusativity in Italian. Further, the subject of an unaccusative verb can appear either before the verb or after the verb.
} 
'substitute' in sports jargon. In Spanish the noun entrante refers to a person who enters, but also to the first course of a meal.

In Italian the word partire forms the agentive nominal partente (salutare $i$ partenti 'say goodbye to the departees', l'elenco dei partenti 'the list of starters'). ${ }^{61}$ In French, there is also the nominal partant, e. g., dire adieu aux partants, les partants d'une course automobile.

From the verb piacere in It. is derived the interesting noun piacione, which can be translated into English as 'yes-man, backscratcher, apple-polisher'. The French expression for 'yes-man' is béni-oui-oui.

In some cases, if a verb does not have a derived agentive nominal, its synonym could be the derivation base, e. g., the Italian verb scappare 'to run away' has a synonym fuggire from which are derived the nouns fuggitivo (i fuggitivi sono stati raggiunti dal gruppo 'the fugitives have been reached by the group') and fuggiasco (arrivarono molti fuggiaschi dai territorî invasi 'many fugitives came from the invaded territories'). This corresponds to the French fugitif and the Spanish fugitivo. ${ }^{6}$

It is interesting that the Italian. verb salire 'to go up' has the derived agentive nominal salitore 'climber', while the noun scenditore (from scendere 'to go down') is not registered any of the cited dictionaries. However, the noun scenditore is used for 'downhill skier, downhiller'. ${ }^{63}$ In French, the equivalent of the first noun is grimpeur ( $\leftarrow$ grimper), while the second, in the meaning of 'downhill skier', is covered by descendeur ( $\leftarrow$ descendre).

The Italian suffix -tore is very productive for agentive nominals (peccare 'to sin' $\rightarrow$ peccatore, camminare 'to walk' $\rightarrow$ camminatore) ${ }^{64}$ but this suffix cannot form the eventive nouns of some verbs (venire 'to come', sbagliare 'to make a mistake', andare 'to go', cadere 'to fall'). ${ }^{65}$

\section{Conclusion}

Nominalizations, despite their similarity with verbs, are noticeably different from them. For example, nominals can only be intransitive in Romance languages. Therefore, the only solution, as Alexiadou's main proposal suggests, is to assume that event nominals contain an intransitive version of v, as is located in the structure of unaccusative verbs. In contrast, in Slavic languages nominals can also be transitive. Another counterargument are the Romance languages and especially Slavic languages in which process/event nominals and even agentive nominals can be formed both from unergative and unaccusative verbs, while according to Alexiadou that type

\footnotetext{
${ }^{61}$ In Croatian this can be kretalac, kretač, but also putnik or odlaznik.

62 The corresponding Spanish verb is huir $(<$ vulg. Lat. fugire $)$.

${ }^{63}$ It is also used in the nominalised idiomatic expression scenditore in piazza, which denotes a person who does the action scendere in piazza, meaning 'to protest at public demonstrations' - e. g., coscienze di qualche scenditore in piazza sventolante bandiera bianca (http://roma2011.blogosfere.it/post/24116/bersani-come-to [18.05.2016]).

${ }^{64}$ Fr. pécher $\rightarrow$ pécheur, marcher $\rightarrow$ marcheur; Sp. pecar $\rightarrow$ pecador, caminar $\rightarrow$ caminante.

${ }^{65}$ From the verb cadere 'to fall', there is a form cadente which is only an adjective, but as we have seen, the corresponding Croatian verb padati has its agentive nominal padač (as in Pol. padacz, while the Slo. word padalec means 'parachutist'. The Croatian verb ići 'to go' does not form the agentive nominal, but the verb hodati 'to walk' does: hodač (Pol. chodzacy, Slo. sprehajalec). The verb doći 'to come' also has an agentive nominal: dolaznik, (Pol. przybysz, Slo. prihajač).
} 
of nominals is unaccusative. That is why she assumes that unaccusative verbs do not differ from unergative verbs in those languages. We, however, argue that the explanation for unaccusativity/unergativity offered by DM theory which takes an exclusively syntactic approach does not satisfactorily take account of unaccusativity/unergativity. In order to explain the possibility of forming event nominals from unaccusative verbs, some authors (Alexiadou 2001; Hale/Keyser 1998; Marantz 2001) claim that imperfective unaccusative verbs resulting from the imperfectivisation of perfective verbs lose their marker of unaccusativity (padač 'faller', hodač 'walker'), in other words, perfective verbs actually become imperfective, by which its argument structure changes. They argue that these two types of unaccusative verbs (perfective/imperfective) have different syntactic behaviors. Therefore, behind this recategorization, according to scholars of DM, remains the fact that perfective verbs after imperfectivisation cease to behave as inaccusative verbs, i. e. their argument stucture is changed as well as the argument structure of nouns derived from those verbs. However, according to our investigation, there are some problems with this analysis, because there are cases in which nominals derived from imperfective and perfective unaccusative verbs manifest the same morphosyntactic behavior (Cro. pasti $i_{\text {perfective }} /$ padati $i_{\text {imperfective }} \rightarrow$ pad/padanje; pad je trajao pol sata/padanje je trajalo pol sata 'the fall lasted half an hour'). This means that there is no perfect diagnosis that can determine unaccusativity and its influence on the structural behavior of deverbal nouns. Further, they ignore the fact that all word formation resulting from adding the Slavic suffix -nje/-anie (among others) to perfective verbs is limited regardless of whether the verbs are transitive, ergative or unaccusative. That means that they depend on something else. Since unaccusative predicates have no external argument, it is expected that they do not participate in the formation of nominals for complex events, yet there are nominals of this kind that are formed from unaccusative predicates. The question of the relationship between aspect and event - specifically the issues of the connection between perfectiveness/imperfectiveness and result/event; the relationship of the aspect marker of the stem and the interpretation of the derived nominal; the question of the true origin of aspect markers (syntactic or lexical); genitive marking within nominal groups; and resolving the dual interpretation of nominals - cannot be solved within the DM framework. Slavic nominals ending in -nje/-anie and Romance nominals ending in -mento/-ment/-miento and -zione/-tion/-cion challenge the assumption that imperfectiveness might have any special relationship to event because it is used to form nominals from all types of verbs without limitations and can be interpreted in two different ways (Event and Result).

The affix can determine which argument a derived nominal requires. For example, the suffix $a c$ requires Agent, the suffix -ik requires Patient, and the suffix -zione requires Theme. Furthermore, there are some suffixes with underspecified eventive readings, such as -mento/-ment/miento (short reading), -aggio/-age/-aje (long reading), -zione/-tion/-cion (short or long reading). The readings mostly depend on the independent properties of the verbal base, i. e., the availability of the event argument is tied to certain suffixes. In Slavic and Romance languages, unlike in English, there are no nominals formed with a suffix that has only event interpretation. In this paper, we have attempted to show that the rules that regulate the phrasal architecture of base verbs are different in kind from the rules that govern the internal structure of derived words.

Alexiadou and Grimshaw (2008) assume that purely event nominals cannot pluralize across languages, especially certain telic event nominals. But this paper gathers evidence showing that 
eventivity/(a)telicity alone does not explain the asymetric behaviour of event nominalizations with respect to the possibility of pluralizing. In fact, a large number of event nominals, including telic ones, permit pluralization.

Concerning the difference between the categories of verb and noun, we assume that noun and verb operate as distinct label categories in so far as grammatical category specific information is critical in processing morphosyntactic patterns. Comparing language to a painting, the lateeighteenth-century grammarian Destutt de Tracy (cf. Foucault 1973: 95) defined nouns as form, adjectives as colours, and the verb as the canvas itself, upon which the colours are visible. Foucault argues that discourse can express the whole content of representation - the most general and most elementary form of thought - since it is created of words that name, part by part, what is given to representation: "the word designates, that is, in its very nature it is a noun or name" (ibid: 97).

We conclude that certain delimited aspects of morphology can be viewed as an autonomous part of grammar because the syntactic notions such as head, head movement, aspect, argument structure, eventivity/(a)telicity are distinct in nature and should be kept as such. Therefore, these notions in syntax are separate from the corresponding notions when used morphologically.

\section{References}

Alcina Franch, Juan/Blecua, José Manuel (1983): Gramática española. Barcelona: Ariel.

Alexiadou, Artemis (2001): Functional structure in nominals: nominalization, and ergativity. Amsterdam: John Benjamins.

Alexiadou, Artemis/Grimshaw, Jane (2008): "Verbs, nouns and affixation". SinSpeC 1: 1-16. Allen, Margaret Reece (1978): Morphological Investigations. Michigan: Ann Arbor.

Alonso Ramos, Margarita (2004): Las construcciones con verbos de apoyo. Madrid: Visor Libros.

Alvar Ezquerra, Manuel (dir.) (1999): Diccionario general de la lengua espanola. Barcelona: Biblograf.

Aronoff, Mark (1994): Morphology by Itself. Cambridge (MA): MIT Press.

Aronoff, Mark/Anshen, Frank (2001): "Morphology and the Lexicon. Lexicalization and Productivity". In: Spencer, Andrew/Zwicky, Arnold M. (eds.): The Handbook of Morphology. Oxford, Blackwell: 237-247.

Babić, Stjepan (1991): Tvorba riječi u hrvatskom književnom jeziku. Zagreb: Hrvatska akademija znanosti i umjetnosti/Globus.

Badia, Toni (2002): "Els complements nominals". In: Solà, Joan et al. (eds.): Gramàtica del Català Contemporani Vol. 3. Barcelona, Empúries: 1591-1640.

Bajec, Anton (1950): Besedotvorje slovenskega jezika. 1. Izpeljava samostalnikov. Ljubljana: Slovenska akademija znanosti i umjetnosti.

Baker, Mark (1985): "The Mirror Principle and Morphosyntatic Explanation". Linguistic Inquiry 16/3: 373-415.

Baker, Mark (1988): Incorporation: A theory of grammatical function changing. Chicago: University of Chicago Press.

Balvet, Antonio et al. (2011). "Nomage: an electronic lexicon of French deverbal nouns based on a semantically annotated corpus". In: Benoît Sagot (ed.): Proceedings of the International 
Workshop on Lexical Resources (WoLeR) at European Summer School in Logic, Language and Information (ESSLLI 2011), Ljubljana: 8-15. [http://alpage.inria.fr/ $\sim \mathrm{sa}-$ got/pub/WoLeR_2011_proceedings.pdf] [18.05.2016].

Bertinetto, Pier Marco/Delfitto, Denis (2000): “Aspect vs. Actionality: Why they shoulld be kept apart”. In: Dahl, Östen (ed.): Tense and Aspect in the Languages of Europe. Berlin/New York, Mouton de Gruyter: 189-225.

Birtić, Matea (2008). Unutarnja struktura odglagolskih imenica u hrvatskom jeziku. Zagreb: Institut za hrvatski jezik i jezikoslovlje.

Chomsky, Noam (1995): The Minimalist Program. Cambridge (MA): MIT Press.

Chomsky, Noam (2001): "Derivations by Phase". In: Kenstowicz, Michael (ed.): Ken Hale: A life in language. Cambridge (MA), MIT Press: 1-50.

Cinque, Guglielmo/Rizzi, Luigi (2008): “The cartography of syntactic structures". CISCL Working Papers on Language and Cognition 2, 43-59.

Dardano, Maurizio (2009): Costruire parole. La morfologia derivativa dell'italiano. Bologna: Il Mulino.

Di Sciullo, Anna Maria/Williams, Edwin (1987): On the Definition of Word. Cambridge (MA): MIT Press.

Dubois, Jean (dir.) (2002): Lexis: dictionnaire de la langue française. Paris: Larousse.

Embick, David (1998): "Voice systems and the syntax/morphology interface". MIT Working Papers in Linguistics 32: 41-72.

Fábregas, Antonio/Marín, Rafael (2012): "The role of Aktionsart in deverbal nouns: State nominalizations across languages". Journal of Linguistics 48: 35-70.

Foucault, Michel (1973): The order of things: an archaeology of the human sciences. New York: Vintage Books.

Fowler, George (1996): “Oblique passivization in Russian”. Slavic and East European Journal 40: 519-545.

Grevisse, Maurice/Goosse, André (1995): Nouvelle grammaire française. Bruxelles: De Boeck/Duculot, 2009.

Grimshaw, Jane (1990). Argument Structure, Cambidge (MA): MIT Press.

Hale, Ken/Keyser, Jey (1998): “The basic elements of argument structure". MIT Working Papers in Linguistics 32: 73-118.

Halle, Morris (1997): "Distributed Morphology: Impoverishment and Fission", MIT Working Papers in Linguistics 30: 425-449.

Halle, Morris/Marantz, Alec (1994): "Some key features of Distributed Morphology". MIT Working Papers in Linguistics 21: 275-288.

Harley, Heidi/Noyer, Rolf (1998): "Licensing in the non-lexicalist lexicon: nominalizations, vocabulary items and the Encyclopedia". MIT Working Papers in Linguistics 32: 119-137.

Harley, Heidi/Noyer, Rolf (1999): "State-of-the-Article: Distributed Morphology". GLOT International 4/4: 3-9.

Lang, Mervyn F. (2009): Formación de palabras en espanol: morfología derivativa productiva en el léxico moderno (translated by Alberto Miranda Poza). Madrid: Cátedra.

Lieber, Rochelle (1992): Deconstructing morphology: word formation in syntactic theory. Chicago: The University of Chicago Press. 
Marantz, Alec (1997): "No escape from syntax: Don't try morphological analysis in the privacy of your own lexicon”. University of Pennsylvania Working Papers in Linguistics 4: 201225.

Marantz, Alec (1999): Creating words above and below little v. Cambidge (MA): MIT Press.

Marantz, Alec (2001): "Words". Paper presented at WCCFL20, University of Southern California, Los Angeles.

Picallo, M. Carme (1999): "La estructura del Sintagma Nominal: las nominalizaciones y otros sustantivos con complementos argumentales". In: Demonte Barreto, Violeta/Bosque, Ignacio (eds.): Gramática Descriptiva de la Lengua Española Vol. 1. Madrid, Espasa Calpe: 363-393.

Pollock, Jean-Yves (1989): "Verb Movement, Universal Grammar, and the Structure of IP". Linguistic Inquiry 20, 365-424.

Pustejovsky, James (1995): The generative lexicon. Cambridge (MA): MIT Press.

Sabatini, Francesco/Coletti, Vittorio (dir.) (2008): Il Sabatini Coletti: dizionario della lingua italiana. Firenze: Sansoni.

Salvi, Giampaolo (1988): "La frase semplice". In: Renzi, Lorenzo/Salvi, Giampaolo/Cardinaletti, Anna (eds.): Grande grammatica italiana di consultazione. La frase. I sintagmi nominale e preposizionale Vol. 1., Bologna, il Mulino: 29-114.

Scalise, Sergio (1994): Morfologia. Bologna: Il Mulino.

Selkirk, Elisabeth O. (1982): The Syntax of Words. Cambridge (MA): MIT Press.

Strutyński, Janusz (2005): Gramatyka polska. Kraków: Wydawnictwo Tomasz Strutyński.

Tekavčić, Pavao (1972): Grammatica storica dell'italiano. Lessico. Vol. 3. Bologna: Il Mulino. Toporišič, Jože (2000): Slovenska slovnica. Maribor: Obzorja.

Travis, Lisa (1984): Parameters and Effects of Word Order Variation. Cambridge (MA): MIT (Dissertation).

Travis, Lisa (2005): “Articulated vPs and the Computation of Aktionsart”. In: Kempchinsky, Paula/Slabakova, Roumyana (eds.): Aspectual Inquiries. New York, Springer Publishers: 69-94.

Zubizarreta, María Luisa (1987): Levels of Representation in the Lexicon and in the Syntax. Dordrect: Foris. 